\title{
Are the Spanish long-term unemployed unemployable?
}

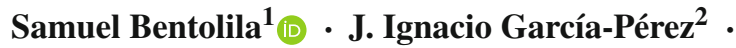 \\ Marcel Jansen ${ }^{3}$
}

Received: 25 January 2017 / Accepted: 17 February 2017 / Published online: 24 March 2017 C The Author(s) 2017. This article is an open access publication

\begin{abstract}
Long-term unemployment reached unprecedented levels in Spain in the wake of the Great Recession and it still affects around 57\% of the unemployed. We document the sources that contributed to the rise in long-term unemployment and analyze its persistence using state-of-the-art duration models. We find pervasive evidence of negative duration dependence, while personal characteristics such as mature age, lack of experience, and entitlement to unemployment benefits are key to understand the cross-sectional differences in the incidence of long-term unemployment. The negative impact of low levels of skill and education is muted by the large share of temporary contracts, but once we restrict attention to employment spells lasting at least 1 month
\end{abstract}

This is a revised version of the Presidential Address delivered by the first author at the 40th Simposio de la Asociación Española de Economía in Girona. We are grateful to two anonymous referees, Manuel Arellano, Rolf Campos, Mario Izquierdo, Ernesto Villanueva, and seminar participants at the Banco de España, the European Central Bank, the International Labor Office, and the University of Edinburgh for comments, to Yolanda Rebollo-Sanz for help with the data, and to Lucía Gorjón and Ingeborg Kukla for excellent research assistance. Bentolila thanks the Economics Department of Universidad Carlos III de Madrid for their hospitality. García-Pérez and Jansen gratefully acknowledge financial support from MINECO/FEDER (Grants ECO2015-65408-R and ECO2015-69631-P).

$\triangle$ Samuel Bentolila

bentolila@cemfi.es

J. Ignacio García-Pérez

jigarper@upo.es

Marcel Jansen

marcel.jansen@uam.es

1 CEMFI, Casado del Alisal, 5, 28014 Madrid, Spain

2 Universidad Pablo de Olavide and FEDEA, Ctra. de Utrera, km. 1, 41013 Sevilla, Spain

3 Universidad Autónoma de Madrid, Fedea and IZA, Ciudad Universitaria de Cantoblanco, 28049 Madrid, Spain 
these factors also contribute to a higher risk of long-term unemployment. Surprisingly, workers from the construction sector do not fare worse than similar workers from other sectors. Finally, self-reported reservation wages are found to respond strongly to the cycle, but much less to individual unemployment duration. In view of these findings, we argue that active labor market policies should play a more prominent role in the fight against long-term unemployment while early activation should be used to curb inflows.

Keywords Long-term unemployment · Great Recession · Duration models · Survival probability $\cdot$ Spain

JEL Classification J63 $\cdot$ J64 $\cdot$ J65 $\cdot$ C41

\section{Introduction}

In the aftermath of the Great Recession, long-term unemployment reached unprecedented levels in Spain. At the worst moment during the crisis, $16 \%$ of the labor force and nearly two out of three unemployed persons (64\%) had been searching for a job for over a year. Since that time, the situation in the labor market has improved considerably, with employment growing at a rate around $2.3 \%$ per year since 2014, but the share of long-term unemployed is still $57 \%$, while the share of unemployed with spells lasting more than 2 years is $42 \%$.

The high incidence of long-term unemployment (LTU) entails a risk for social cohesion and it poses enormous challenges for policymakers. The probability of exit from unemployment tends to fall with duration due to factors such as skill depreciation, loss of motivation, and discrimination on the part of employers. Moreover, health problems due to mental stress, the accumulation of unsustainable levels of debt or housing problems also tend to increase over time. ${ }^{1}$ Reenfranchising the long-term unemployed therefore becomes progressively harder, ${ }^{2}$ exposing individuals to a risk of social exclusion and society at large to high levels of structural unemployment. This state of affairs motivates our work. We start by documenting the factors that have contributed to the buildup of LTU and we subsequently perform an econometric analysis to quantify the impact of individual and aggregate determinants on the probability that an individual enters and exits LTU. The main objectives of our econometric analysis are to isolate the impact of unemployment duration on job-finding rates and to identify the population groups that are most vulnerable. Our empirical approach delivers reduced-form estimates, resulting from the interplay of labor demand and supply decisions, and hence do not have a causal interpretation. For this reason, we also analyze the response of self-reported reservation wages to both unemployment duration and changes in aggregate labor market conditions.

The factors that account for the dismal performance of the Spanish labor market are well-known. Like many other European countries, Spain suffered two consecutive

\footnotetext{
1 See Farré et al. (2015) for evidence on Spain and Winter-Ebmer (2016) for other countries.

2 Hence the title of this article, which is inspired by Saint-Paul (1996).
} 
recessions, the 2008 international financial crisis and the Eurozone crisis, but in the Spanish case these external shocks were compounded by the bursting of a housing bubble and a large-scale banking crisis that led to a severe reduction in bank lending to firms (Jimeno and Santos 2014; Bentolila et al. 2016). The collapse of the construction sector alone added 1.7 million workers, mostly low-educated, to the ranks of the unemployed. Furthermore, all these shocks interacted with institutional factors, such as the dual nature of the Spanish labor market and a rigid system of collective bargaining, that resulted in high worker-turnover due to the massive destruction of temporary jobs and a slow adjustment of negotiated wages. ${ }^{3}$ Here we take the shocks to the Spanish economy as given and pursue an analysis of the mechanisms that generate the high degree of unemployment persistence that has fueled the buildup of LTU.

Our descriptive analysis in Sect. 3 is based on data from the Spanish Labor Force Survey (LFS). It reveals that LTU especially affects older and less educated workers. Nonetheless, even for prime-age male workers we obtain an LTU share close to $60 \%$. Moreover, inspection of longitudinal data indicates a strong negative relationship between the average transition rate from unemployment to employment and the duration of unemployment spells. A key objective of our empirical analysis is to assess to what degree this negative correlation reflects genuine duration dependence. This question is important because such a negative correlation could also be the outcome of dynamic selection. Over time the composition of the pool of unemployed tends to worsen, as the most employable workers leave first. This process generates a negative relationship between the average job-finding rate and duration that is entirely driven by composition effects rather than by a decrease in the exit rate of individual unemployed workers. In other words, duration dependence is mainly a reflection of the lack of demand, while the alternative explanation of dynamic selection would point at the importance of supply-side factors, such as inadequate skills, that result in low job-finding rates from the very start of the unemployment spell.

In order to avoid the potentially confounding role of changes in worker characteristics, in Sect. 4 we estimate state-of-the-art duration models. To account for selection, we estimate similar models for the outflow from both employment and unemployment, and we allow for worker unobserved heterogeneity. To take into account the dual nature of the Spanish labor market, we model flows to and from temporary and open-ended, or permanent, jobs. And, lastly, to properly capture the impact of the unemployment benefit system, we use workers' full employment history to measure their entitlement to contributory benefits. Most of these refinements are absent from the recent literature on long-term unemployment, as described in Sect. 2.

The estimation is performed using the Continuous Sample of Working Lives, which is a large sample of Social Security records. This data set allows us to capture shortterm worker flows which are mostly missed by the LFS. On the other hand, this source does not allow us to distinguish between unemployment and nonparticipation, though we show that this is probably not an important shortcoming. In view of the fact that in Spain-like in other countries-the Great Recession reduced male employment

\footnotetext{
3 From 2010 to 2012, three consecutive labor market reforms introduced profound changes in the collective bargaining system but they failed to address the problem of duality, see Bentolila et al. (2012) and GarcíaPérez and Jansen (2015).
} 
significantly more than female employment, we limit our analysis to the population of native prime-age males. ${ }^{4}$

Our empirical results indicate that in Spain the conditional probability of entering LTU is very large and is significantly raised by receipt of unemployment benefits, mature age, low experience, and-especially once we mitigate the relevance of spells below 1 month-low education and low skill. In agreement with the recent literature on LTU in the US, we also find that duration dependence and not dynamic selection is the primary source of the low job-finding rates of the long-term unemployed.

Temporary contracts help to reduce the risk of LTU conditional on unemployment, but they also cause huge inflows into unemployment. For this reason, it is natural to ask whether temporary contracts are indeed a useful work-sharing arrangement during a crisis. A related question is whether short-duration contracts or placements have a noticeable impact on the subsequent employment prospects of the long-term unemployed or whether employers ignore these spells when assessing prospective employees. Here we take a first step towards answering the latter question by considering a model in which exits to spells below 30 days are treated as censored. Our estimates indicate that temporary jobs especially help specific groups of workers to leave unemployment, namely the least educated and experienced ones.

In Sect. 5 we conduct an exploratory analysis of reservation wages during the Great Recession with a different data source, the Spanish Survey of Family Finances. We find that self-reported reservation wages strongly adjust with the aggregate business cycle and also, though much less, with individual unemployment duration. In Sect. 6 we summarize our findings and argue that higher aggregate demand alone will not solve the LTU problem. Expanding and, especially, improving active labor market policies, linking them to the receipt of unemployment benefits, and intensifying early activation would all be helpful measures. The Appendix includes further empirical results.

\section{Literature review}

Our work adds to a long literature on long-term unemployment in Europe. Overviews of work in this area as of the 1990s appear in Layard et al. (1991) and Machin and Manning (1999). Thereafter the incidence of LTU started to fall and so did the volume of academic work on this issue. However, the rise of LTU in the US in the aftermath of the Great Recession sparked an intense debate on the driving forces behind this phenomenon. In spite of their varying approaches, a common finding from existing studies is that the low exit rates of the long-term unemployed are due to negative duration dependence. On the contrary, changes in the pool of the unemployed due to dynamic selection play at best a modest role. Let us briefly review the literature that is closer to our analysis.

\footnotetext{
4 The term "mancession" was named in The New York Times one of the buzzwords of 2009 (Leibovich and Barrett 2009). Estimates for several of the empirical models presented below, using instead data on Spanish females, are included in the online Appendix to this paper (https://dl.dropboxusercontent.com/u/ 15338248/SpainLTU_onlineappendix.pdf).
} 
In a seminal study, Kroft et al. (2016) construct an augmented matching model to assess the relative role of composition effects, duration dependence, and transitions into nonparticipation in the buildup of LTU and the outward shift of the Beveridge curve in the US. These authors back out duration dependence from observed transition rates and show that it is one of the dominant forces at work, together with cyclical changes in nonparticipation.

In a related study, Krueger et al. (2014) analyze the role of unemployment duration on wages, reemployment chances, and labor force withdrawal. The structure of their paper is similar to ours, but these authors use logistic models to analyze how transition rates to employment and nonparticipation vary with duration. Unlike our case, the authors use data that allow a distinction between unemployment and nonparticipation, but the logistic models that they use do not control for unobserved heterogeneity, a shortcoming which could significantly bias the estimates of duration dependence.

Our work is closest in spirit to Abraham et al. (2016), who use matched firm-worker data to estimate the impact of unemployment duration on subsequent employment outcomes. Their estimation technique compares the difference in pre- and postemployment shares for unemployed workers in seven different duration categories. This procedure allows the authors to control for time-invariant unobserved heterogeneity and for differences in prior employment history. Nonetheless, there are relevant differences with our work. While we observe the entire working history of the individuals in our sample, Abraham et al. (2016) only consider the employment outcomes eight quarters before and after the measurement of unemployment. Moreover, their estimation technique is essentially a difference-in-differences estimator, while we use a duration model.

As stated in the Introduction, we adopt the methodology of duration analysis to address some of the problems found in the previous literature, namely unobserved heterogeneity, state dependence, and self-selection. Recent work on LTU in the US does not treat the problem of selection into unemployment. In contrast we do so by estimating a duration model for the probability of entering unemployment from employment, which depends on worker observed and unobserved characteristics. Since these characteristics also determine the probability of leaving unemployment, we estimate both duration models jointly.

We choose to employ duration models for two reasons. First, our data include a large number of censored employment and unemployment spells. Censoring cannot be dealt with using linear probability models, but ignoring censoring can lead to bias, since then the error term does not satisfy the standard properties in a regression model. Second, we wish to control for explanatory variables that change with duration, as is the case for unemployment benefit entitlements. To this end we need a duration model that takes into account the individual situation each month. In this vein, our study also belongs to the literature on the estimation of the determinants of the probability of leaving employment and unemployment. ${ }^{5}$

\footnotetext{
5 For Spain, see for example García Pérez (1997), Bover et al. (2002), Bover and Gómez (2004), GarcíaPerez and Muñoz-Bullón (2011), Arranz et al. (2010), Arranz and García-Serrano (2014), Carrasco and García-Pérez (2015), and Nagore and van Soest (2016b). Our work here especially builds on Rebollo-Sanz and García-Pérez (2015).
} 
Lastly, here we also pay close attention to the dual structure of the labor market. Studying LTU in a dual labor market raises some interesting issues for understanding its determinants that, to the best of our knowledge, have not been addressed yet in the European literature.

\section{The legacy of the Great Recession}

In this section we provide several pieces of descriptive evidence on the nature of LTU in Spain based on the Labor Force Statistics. We begin by showing the unprecedented increase in LTU as a result of the Great Recession, we then discuss the incidence of LTU for different population groups, and we end with a review of the evolution of the main labor market flows during the crisis. Our discussion of the flows includes preliminary evidence on the existence of duration dependence and highlights the thin line between unemployment and nonparticipation.

\subsection{The unprecedented rise in LTU}

Figure 1 plots unemployment rates by duration, expressed as a share of the labor force, for the period between 1976 and 2016. The three lines represent, respectively, short-term unemployment (STU, up to 1 year), long-term unemployment between up to 2 years, and very long-term unemployment (VLTU), which refers to spells lasting two or more years. The short periods between vertical bars indicate recessions. Their

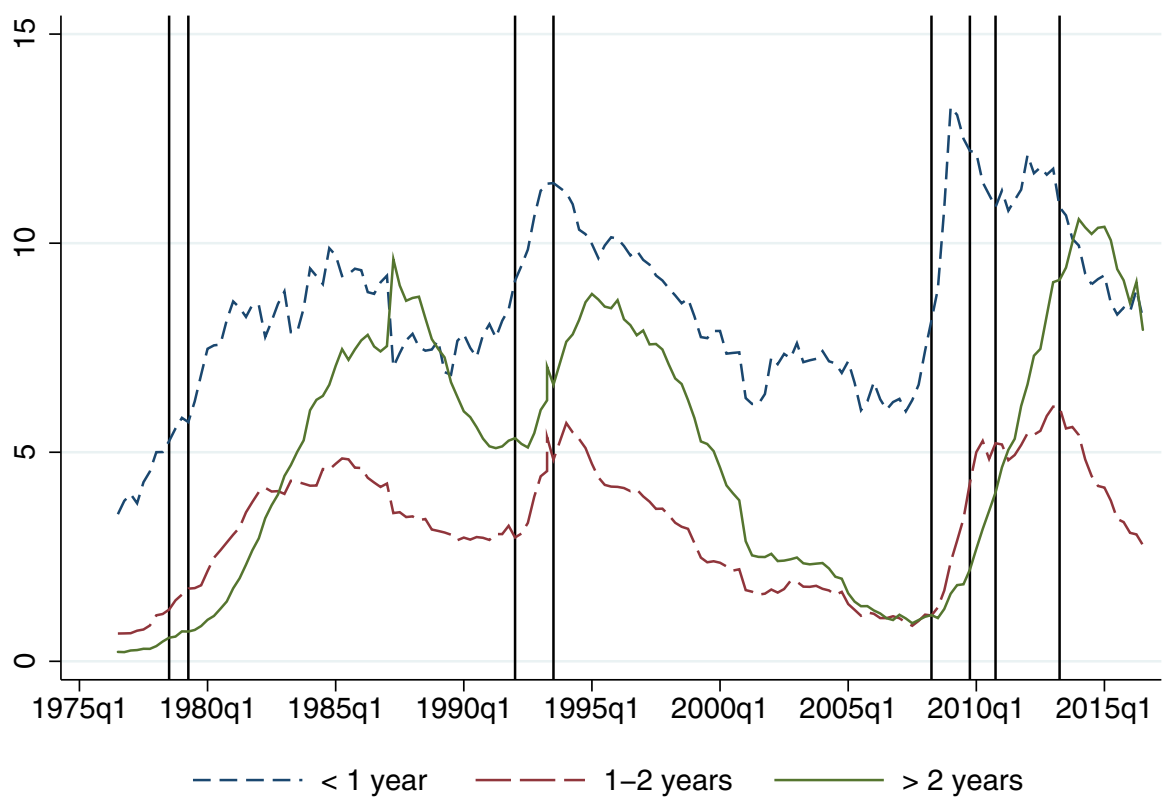

Fig. 1 Duration-specific unemployment rates in Spain, 1976Q3-2016Q3 (\% of labor force). Note Recessions are indicated by vertical bars. Sources: INE, Encuesta de Población Activa and, for recession dates, Spanish Economic Association, Spanish Business Cycle Dating Committee 


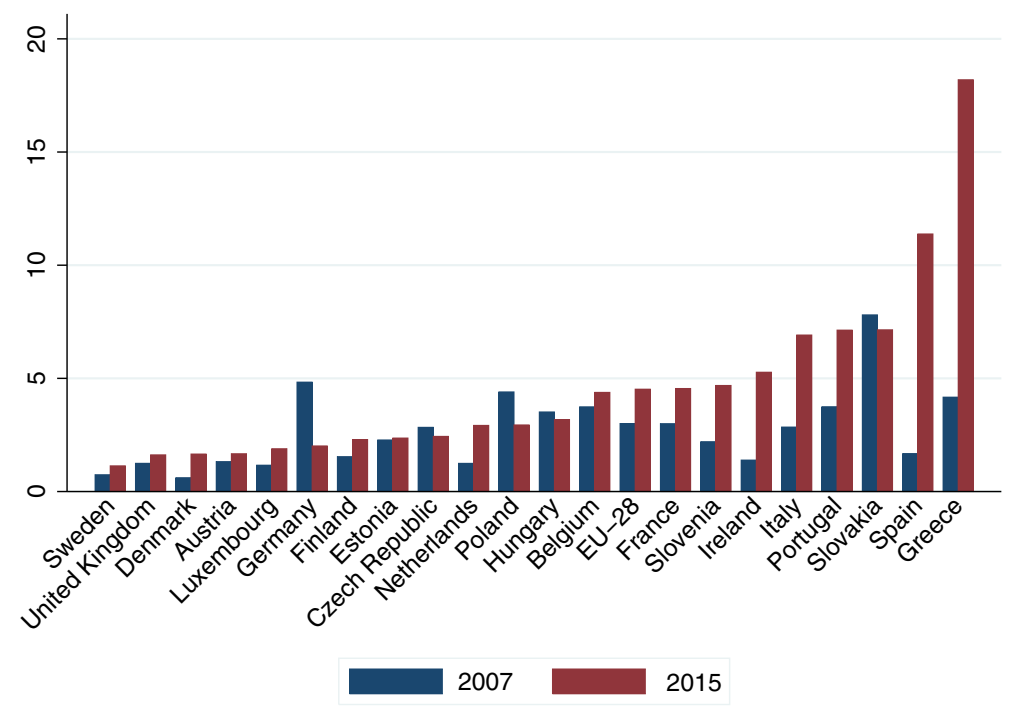

Fig. 2 Long-term unemployment before and after the Great Recession in selected EU countries, 2007 and 2015 (\% of labor force). Source: Organisation for Economic Co-operation and Development, Annual Labour Force Statistics

purpose is to highlight the cumulative effect of the two recent recessionary periods, the first one unleashed by the financial crisis in the US after the fall of Lehman Brothers and the second one caused by the Eurozone crisis.

Inspection of Fig. 1 shows that all three duration-specific unemployment rates reached record levels at distinct moments during the crisis. While STU peaked at the onset of the first recession, LTU continued to grow until the end of the second recession, and VLTU peaked even later. At its peak, 10.6\% of the Spanish labor force was unemployed for more than 2 years. Since that time, the incidence of VLTU has dropped to a level of $7.9 \%$ in 2016Q3, but almost two-thirds of the people remaining in this group (63.4\%) have been unemployed for at least 4 years.

The levels of LTU are not only striking from a historical perspective. Spain also stands out internationally, as is shown in Fig. 2. In 2015, its LTU rate (11.4\%) was the second-highest in the EU, exceeding the EU average by almost 7 percentage points. ${ }^{6}$ Interestingly, four out of the six EU member states with the highest LTU rates participated in an EU-sponsored bailout program. This evidence points at the importance of the deep and prolonged contraction of aggregate demand in these countries as one of the main drivers of the rise in LTU. Moreover, Greece, Italy, Portugal, and Spain - as well as France - are countries with dual labor markets that entered the crisis with a rigid system of collective bargaining. These institutional features and the resulting delay in wage adjustment also seem to have played an essential role in the buildup of LTU in these countries (Bentolila and Jansen 2016).

\footnotetext{
6 Notice that Eurostat reports lower figures for the incidence of LTU than the Spanish Statistical Institute (INE), as it uses a different definition. Eurostat measures the length of unemployment spells as the period since the end of a person's last job. INE, on the contrary, exploits information on search duration.
} 
Table 1 Participation, employment, and unemployment rates, and LTU share before and after the Great Recession in Spain, 2007Q2-2016Q2 (\%). Source: INE, Encuesta de Población Activa

\begin{tabular}{|c|c|c|c|c|c|c|c|c|}
\hline & \multicolumn{2}{|c|}{ Participation rate } & \multicolumn{2}{|c|}{ Employment rate } & \multicolumn{2}{|c|}{ Unemployment rate } & \multicolumn{2}{|c|}{ LTU share } \\
\hline & 2007Q2 & 2016Q2 & 2007Q2 & 2016Q2 & 2007Q2 & 2016Q2 & 2007Q2 & 2016Q2 \\
\hline Total & 72.1 & 74.6 & 66.4 & 59.6 & 8.0 & 20.0 & 27.8 & 59.8 \\
\hline \multicolumn{9}{|l|}{ Gender } \\
\hline Male & 82.0 & 79.6 & 76.9 & 64.9 & 6.2 & 18.5 & 24.1 & 58.0 \\
\hline Female & 62.0 & 69.5 & 55.5 & 54.3 & 10.4 & 21.9 & 30.8 & 61.5 \\
\hline \multicolumn{9}{|l|}{ Age } \\
\hline 16-24 years old & 52.4 & 37.3 & 42.9 & 20.0 & 18.1 & 46.5 & 16.0 & 40.2 \\
\hline 25-34 years old & 86.6 & 87.7 & 80.1 & 68.0 & 7.5 & 22.4 & 24.9 & 56.1 \\
\hline 35-44 years old & 84.5 & 90.5 & 78.8 & 75.4 & 6.7 & 16.8 & 27.2 & 58.8 \\
\hline 45-54 years old & 76.8 & 84.5 & 72.1 & 69.9 & 6.1 & 17.3 & 39.1 & 67.9 \\
\hline 55-64 years old & 45.0 & 55.3 & 42.4 & 46.0 & 5.7 & 16.9 & 55.6 & 77.6 \\
\hline \multicolumn{9}{|l|}{ Education } \\
\hline Primary & 53.5 & 54.3 & 47.8 & 35.2 & 10.6 & 35.2 & 33.0 & 65.2 \\
\hline Secondary, 1st stage & 70.9 & 69.6 & 64.1 & 51.0 & 9.6 & 26.8 & 26.5 & 62.0 \\
\hline Secondary, 2nd stage & 74.3 & 72.6 & 68.3 & 58.1 & 8.0 & 20.0 & 26.3 & 55.7 \\
\hline College & 85.3 & 88.0 & 80.8 & 77.7 & 5.3 & 11.7 & 26.3 & 56.7 \\
\hline \multicolumn{9}{|l|}{ Nationality } \\
\hline Native & 57.1 & 57.4 & 52.9 & 47.1 & 7.3 & 17.9 & 31.3 & 60.8 \\
\hline Foreign & 76.2 & 73.2 & 67.2 & 55.1 & 11.9 & 24.8 & 15.2 & 55.9 \\
\hline
\end{tabular}

Data are shares of source population

Next, returning to the case of Spain, we observe a considerable degree of crosssectional variation in the incidence of LTU. In most cases there exists a strong correlation between the rise in STU and LTU by demographic group. However, changes in nonparticipation and shifts in the distribution of labor demand also play a role. By way of illustration, Table 1 provides a breakdown of the changes in labor force participation, employment, and unemployment for different worker characteristics. Apart from the standard unemployment rate, the table also reports cohort-specific LTU shares. The latter are defined as the proportion of long-term unemployed among the unemployed in each group. The LTU shares provide a proxy for the conditional probability that an unemployed worker in each of the groups ends up in LTU.

The reported data confirm a number of well-known facts. The drop in employment rates affected men more than women, and was strongly concentrated among youth, low-educated workers with at most mandatory education, and immigrants. In 2016 the same cohorts also present the highest LTU rates as a share of the labor force (not shown), ${ }^{7}$ but in the cases of youth and immigrants these high LTU rates are mostly driven by the relatively high inflow into unemployment. Indeed, both groups of work-

\footnotetext{
${ }^{7}$ Notice that cohort-specific LTU rates can be computed as the product of cohort-specific unemployment rates and LTU shares.
} 
ers have below-average LTU shares. While $59.8 \%$ of the unemployed in our reference period were long-term unemployed, this figure is reduced to $40.2 \%$ in the case of youth and to $55.9 \%$ for non-natives. On the contrary, LTU shares are all close to $60 \%$ for the remaining demographic groups. This uniformity is a striking finding that highlights the widespread nature of LTU in Spain. College education seems to provide some protection against the risk of LTU, but the difference between the LTU share of collegeeducated workers and those with at most primary education is equal to only 8 percentage points (pp). Similarly, even for prime-age workers we obtain an LTU share of $59 \%$.

Finally, older unemployed workers clearly seem to be the most vulnerable group. They face a relatively low risk of unemployment, but more than two-thirds of the unemployed in the age bracket from 45 to 54 years old are long-term unemployed, and for those who are 55 and over this share is a staggering $77.6 \%$. Given these comparatively high LTU shares, one might have expected a rise in nonparticipation for this group, but the reverse is true. Between 2007 and 2016 the labor force participation rate of the oldest cohort increased by $10.3 \mathrm{pp}$, from 45 to $55.3 \%$. Part of the increase in the LTU rate of the oldest workers may therefore be driven by a drop in the transition rate to nonparticipation. Two other cohorts for which we observe marked changes in participation rates during the crisis are youth and women. In our econometric analysis below we avoid the potentially confounding role of these changes in participation rates by restricting the analysis to males aged $25-54$ years old.

\subsection{The role of mismatch and composition effects}

Apart from the drop in aggregate labor demand, the economic crisis has also induced profound shifts in the relative demand for skill and the distribution of employment by industry. The two major shifts are the fall in the demand for low-educated workers and the collapse of the construction sector. In 2007, this sector accounted for $13 \%$ of total employment and 9 years later its share had fallen to $6 \%$. In absolute terms, the collapse of the construction sector caused a maximum loss of 1.74 million, mostly low-skilled jobs during the crisis, but this is not the whole picture. ${ }^{8}$ From peak to trough Spain lost three million jobs that were previously occupied by workers with no more than compulsory education. Moreover, the sharp drop in the employment of low-educated workers contrasts with a slight increase in the employment of university graduates.

A straightforward procedure to illustrate the degree of mismatch between the demand and supply of labor and to gauge its importance for the buildup of LTU is to compare the characteristics of the pool of employed and unemployed workers. The former provides an approximation to labor demand while the composition of the pool of unemployed workers provides a proxy for the characteristics of labor supply. Once again we distinguish between STU, LTU, and VLTU. Moreover, in addition to the personal characteristics listed before, in Table 2 we also provide a breakdown by the industry of the unemployed workers' previous job. This decomposition, which is unavailable from the LFS, is computed from the administrative records of the Muestra

\footnotetext{
8 This calculation is based on data from the Spanish Labor Force Survey and takes 2008Q1 as the reference period. The breakdown of employment by industry is not consistent before this date.
} 
Table 2 Employment and unemployment breakdown by duration and population group in Spain, $2016 \mathrm{Q} 2$ (\%). Sources: INE, Encuesta de Población Activa and for industry breakdown Ministerio de Empleo y Seguridad Social, Encuesta Continua de Vidas Laborales

\begin{tabular}{|c|c|c|c|c|}
\hline & \multirow[t]{2}{*}{ Employed } & \multicolumn{3}{|c|}{ Unemployed } \\
\hline & & Short-term & Long-term & Very long-term \\
\hline \multicolumn{5}{|l|}{ Gender } \\
\hline Male & 54.5 & 51.3 & 45.8 & 48.5 \\
\hline Female & 45.5 & 48.7 & 54.2 & 51.5 \\
\hline \multicolumn{5}{|l|}{ Age } \\
\hline 16-24 years old & 4.4 & 22.5 & 18.4 & 7.0 \\
\hline 25-34 years old & 20.7 & 26.0 & 27.4 & 20.8 \\
\hline $35-44$ years old & 31.9 & 26.1 & 23.7 & 25.8 \\
\hline 45-54 years old & 27.5 & 18.3 & 19.9 & 28.2 \\
\hline 55-64 years old & 15.5 & 7.0 & 10.6 & 18.2 \\
\hline \multicolumn{5}{|l|}{ Education } \\
\hline Primary & 6.6 & 12.4 & 12.5 & 16.4 \\
\hline Secondary, 1st stage & 27.4 & 37.6 & 37.2 & 42.6 \\
\hline Secondary, 2nd stage & 23.9 & 26.1 & 23.3 & 21.5 \\
\hline College & 42.1 & 23.8 & 26.9 & 19.5 \\
\hline \multicolumn{5}{|l|}{ Nationality } \\
\hline Native & 85.3 & 78.8 & 77.2 & 78.7 \\
\hline Foreign & 14.7 & 21.2 & 22.8 & 21.3 \\
\hline \multicolumn{5}{|l|}{ Industry of previous job } \\
\hline Primary & 4.1 & 0.1 & 3.6 & 3.0 \\
\hline Manufacturing & 14.0 & 8.6 & 9.7 & 13.5 \\
\hline Construction & 6.1 & 11.3 & 9.2 & 19.3 \\
\hline Wholesale and retail trade & 16.6 & 16.3 & 16.4 & 14.5 \\
\hline Finance and real state & 3.1 & 1.5 & 1.9 & 1.7 \\
\hline Professional and business services & 20.5 & 24.7 & 19.0 & 20.5 \\
\hline Education & 6.7 & 3.5 & 4.1 & 3.0 \\
\hline Health care & 8.1 & 5.5 & 5.4 & 4.6 \\
\hline Leisure and hospitality & 7.8 & 16.5 & 13.1 & 4.4 \\
\hline Scientists, artists and other & 13.0 & 12.0 & 17.6 & 15.5 \\
\hline
\end{tabular}

The breakdown by industry corresponds to 2015 . Columns add up to 100 by characteristic. Short-term denotes unemployment for up to 1 year, long-term between one and 2 years, and very-long term for more than 2 years

Continua de Vidas Laborales (see Sect. 4.2), while the rest of the data are computed using the Spanish LFS.

Our main interest concerns the groups of workers that are more prominent among the unemployed than among the employed. Inspection of the data shows that this is the case for youth, immigrants, low-educated individuals - i.e. those without completed uppersecondary education-and workers from the construction sector. For the latter two groups the degree of mismatch is increasing roughly monotonically with unemploy- 
ment duration, while the opposite is true for youth and immigrants. For example, the construction sector currently accounts for $6.1 \%$ of employment and the workers from this sector represent $11.3 \%$ of the short-term unemployed and $19.3 \%$ of the very longterm unemployed, while the corresponding figures for individuals with primary education are, respectively, 6.6, 12.4, and 16.4\%. Individuals who belong to these two groups therefore face a comparatively high conditional probability of ending up in VLTU. This is not so for youth, while for immigrants the share is roughly unchanged as duration increases. Lastly, workers above 45 years of age make up a comparatively small share of the short-run unemployed and a comparatively large share of the long-term unemployed, and this share is increasing with duration, so they appear to face a high conditional probability of ending up in VLTU. Still, as already indicated, only a rigorous multivariate analysis of flows - which we carry out in Sect. 4 - can establish the relationship between worker characteristics and the probability of entering and leaving LTU.

The relatively strong concentration of disadvantaged workers among the unemployed with spells that last more than 2 years poses a challenge to policymakers. Our analysis below indicates that these workers have very low job-finding rates which have, moreover, barely improved in recent times. Nonetheless, the contribution of composition effects to the buildup of the current stock of long-term unemployed seems to have been modest compared to the contribution of the strong rise in the disaggregated LTU shares for most cohorts. In Bentolila et al. (2017) we construct a counterfactual series for the overall LTU share in which the weights of different groups-formed by crossing age, gender, education, and nationality-in unemployment are allowed to change in accordance with the actual data, while the group-specific LTU shares are fixed at their pre-crisis values in 2008Q3. By construction, the counterfactual LTU shares for the reference period coincide with the pre-crisis minimum of the actual LTU shares. While this is a rough exercise that excludes the role of time-varying industry shares, it is telling that it indicates that composition effects account for only $10 \%$ of the increase in the LTU share from 2008Q3 to 2016Q2.

\subsection{Labor market flows during the crisis}

In the previous sections we have provided evidence on the evolution of the stocks of employed (E), unemployed (U), and nonparticipating (N) workers. The purpose of this section is to describe the evolution of the flows among these states. To be consistent with the empirical analysis in the next section, we distinguish between permanent and temporary jobs, and we restrict our sample to male prime-age workers (25-54 years old). We use aggregates constructed from LFS longitudinal panel data using population weights, measured as three-quarter centered moving averages so as to reduce seasonal volatility.

We begin with the initial impulse to the rise in unemployment, i.e. the increase in the transition rates between employment and unemployment at the onset of the two recent recessions. In the left-hand panel of Fig. 3 we observe a sharp increase in the termination of temporary jobs at the start of the first recession and another jump in the second recession. The spikes in dismissals of permanent workers are even more apparent in the right-hand panel, though it should be noted that the separation rate of 
(a)

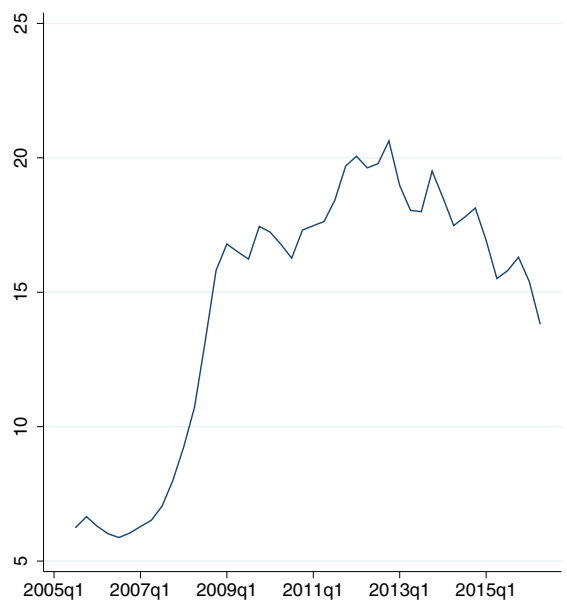

(b)

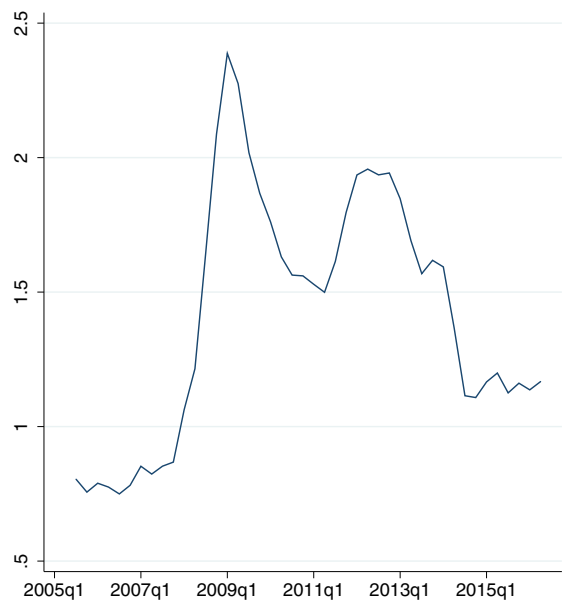

Fig. 3 Quarterly flow rates into unemployment by contract type in Spain, 2005Q3-2016Q2 (\%) a Temporary job, $\mathbf{b}$ Permanent job. Note Rates are computed with respect to the reference population in the preceding quarter. Source: INE, Encuesta de Población Activa

(a)

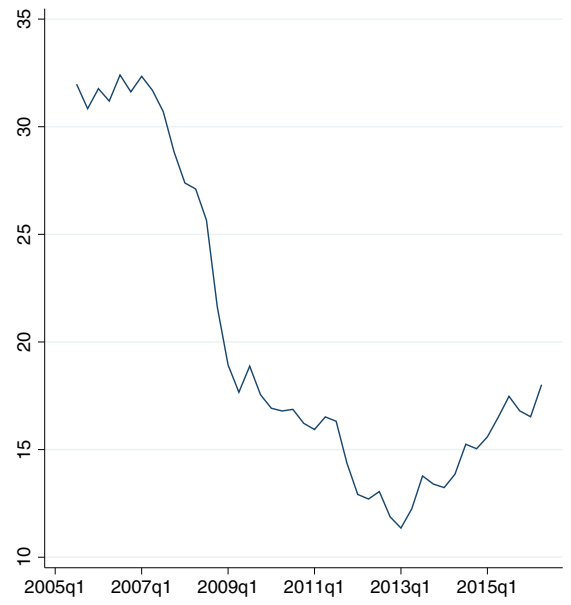

(b)

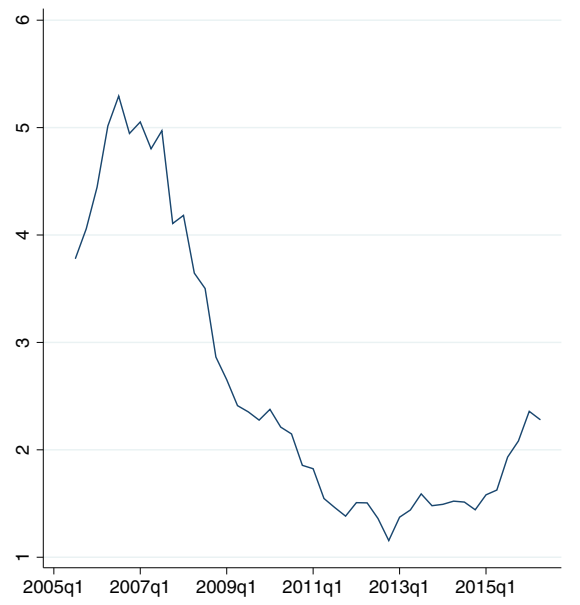

Fig. 4 Quarterly flow rates into employment by contract type in Spain, 2005Q3-2016Q2 (\%) a Temporary job, b Permanent job. Note Rates are computed with respect to the reference population in the preceding quarter. Source: INE, Encuesta de Población Activa

permanent jobs is almost a factor of magnitude smaller than the one for temporary jobs. Overall, between 2008 and 2013, the quarterly transition rate between temporary employment and unemployment more than doubled — and even today it is still substantially higher than in 2008. By contrast, the transition rate between permanent employment and unemployment is currently close to its pre-crisis level.

Our next graph, Fig. 4, depicts the transition rates in the opposite direction, namely from unemployment to employment, on either permanent or temporary 


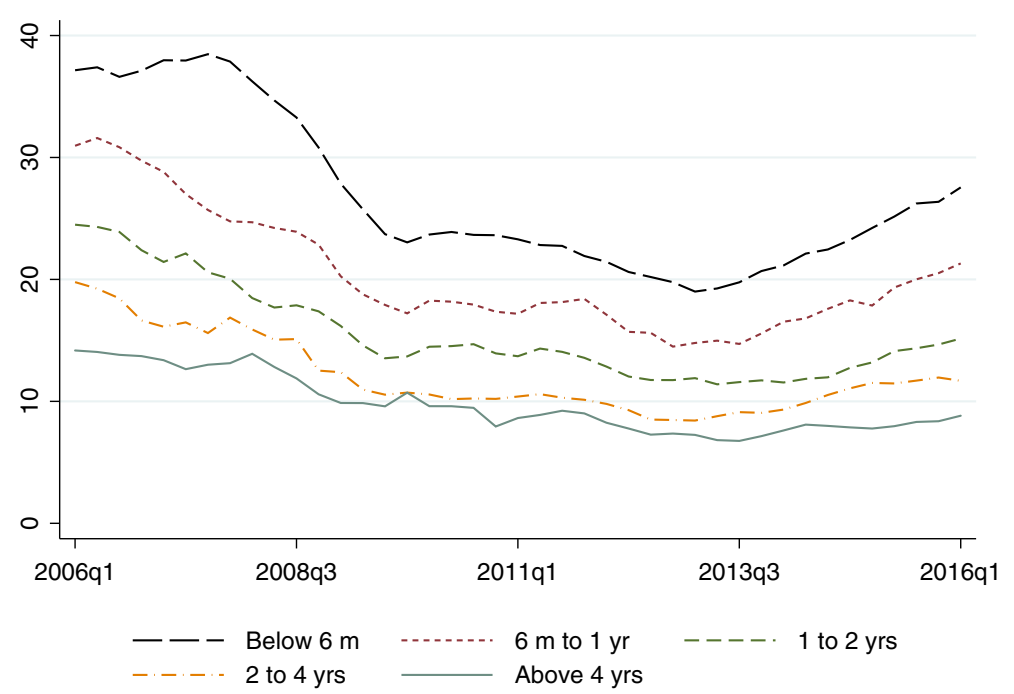

Fig. 5 Unemployment duration-specific transition rates to employment in Spain, 2006Q1-2016Q1 (\%). Source: INE, Encuesta de Población Activa

contracts. Both transition rates fell dramatically during the crisis and are still far below their pre-crisis levels. In the case of temporary jobs the average quarterly transition rate fell by almost $20 \mathrm{pp}$, from a pre-crisis level of around $32 \%$ to a minimum of $12 \%$, and its current level lies around $17 \%$. The quarterly transition rate from unemployment to permanent employment follows a similar pattern, but once again the rates are almost an order of magnitude smaller than in the case of temporary jobs. Before the crisis, around 5\% of unemployed males managed to transit from unemployment to a permanent job within a quarter, while currently only close to $2 \%$ do. The above-mentioned rates are averages and do not account for changes in the pool of unemployed, but they indicate a dramatic increase in the average length of unemployment spells and thereby a higher risk of LTU during the crisis.

In view of our focus on LTU, it is worth checking whether the flow rate from unemployment to employment falls with duration. To this aim, Fig. 5 represents quarterly exit rates to employment according to the duration of unemployment. There is a clear gradient, with the exit rate falling with the spell length. And the differences are huge: at the end of the expansion, around $37 \%$ of workers who had been unemployed for up to 6 months left within a quarter, whereas only $14 \%$ of those who had been unemployed for 4 years or more did so. During the recession all exit rates fell, but differences across duration groups shrank significantly. Then, when the recovery arrived, differences widened again, with the exit rates of the long-term unemployed increasing by less than those of the short-term unemployed, a situation which has reinforced their chances of remaining stuck in unemployment. This is prima facie evidence of the presence of duration dependence, but at this stage we cannot exclude the alternative explanation of dynamic selection. Namely, that over time the composition of the pool of the unemployed may worsen, as the most employable workers leave 


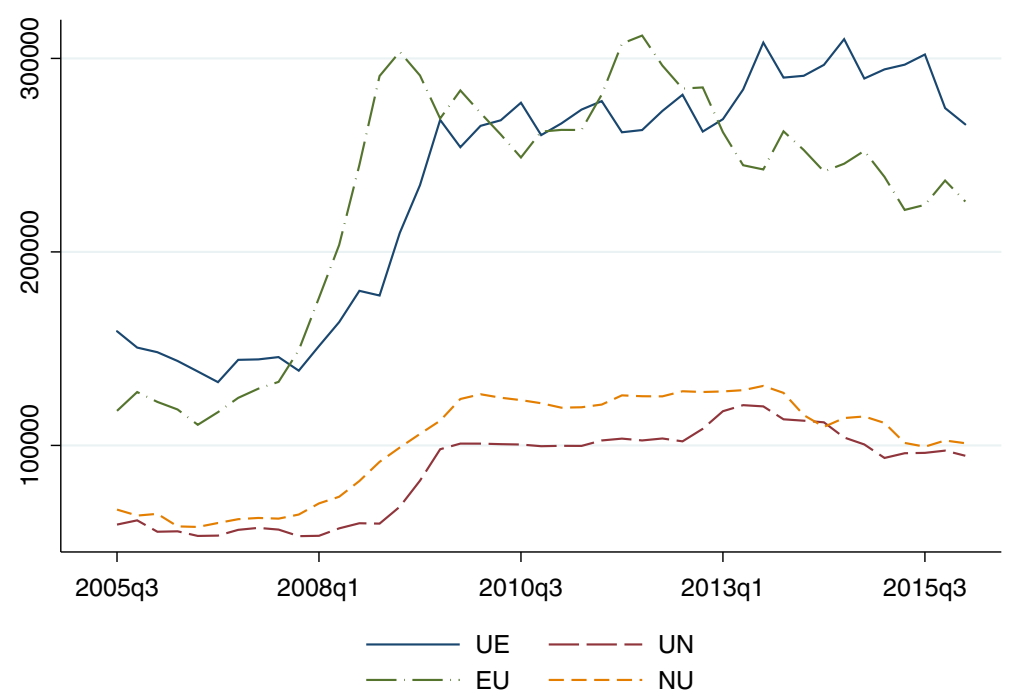

Fig. 6 Quarterly flows to/from unemployment in Spain, 2005Q3-2016Q1 (persons). Note E employment, $U$ unemployment and $N$ nonparticipation. Source: INE, Encuesta de Población Activa

first, and this process of selection also generates a negative relationship between the average job-finding rate and duration. We address this issue rigorously in Sect. 4.

The foregoing evidence highlights the dramatic changes that took place during the crisis in the flows between employment and unemployment. It also reveals the overwhelming dominance of temporary jobs vis-à-vis permanent jobs in labor market flows, as well as a clear deterioration in the quality of new jobs. Now an even larger share of the newly created jobs are temporary and these jobs are shorter now than before the crisis. It is important to take this aspect into account, because it is not clear a priori to what degree relatively short-duration temporary jobs may help long-term unemployed persons to restore their working career after several years in unemployment. 9

Another relevant issue relates to the transitions into and out of nonparticipation. The participation rates of prime age males are fairly constant during the crisis. Nonetheless, these net rates hide frequent movements into and out of nonparticipation. Figure 6 depicts absolute gross flows to and from unemployment from 2005 to 2016. It is apparent that the recession brought about a very large jump in absolute flows between employment and unemployment, but also that many people enter or leave nonparticipation from one quarter to the next. These flows are equivalent to at least one-third of those between employment and unemployment. According to LFS definitions, workers are considered to be employed if they have worked for at least $1 \mathrm{~h}$ in the survey reference week, unemployed if they are not employed, they have searched for a job during the previous month, and they are also available to start work within 2 weeks, and nonparticipants otherwise. These definitions

\footnotetext{
9 Nagore and van Soest (2016a) analyze the change in the behavior of labor market flows during the crisis using the Spanish Social Security data.
} 
(a)

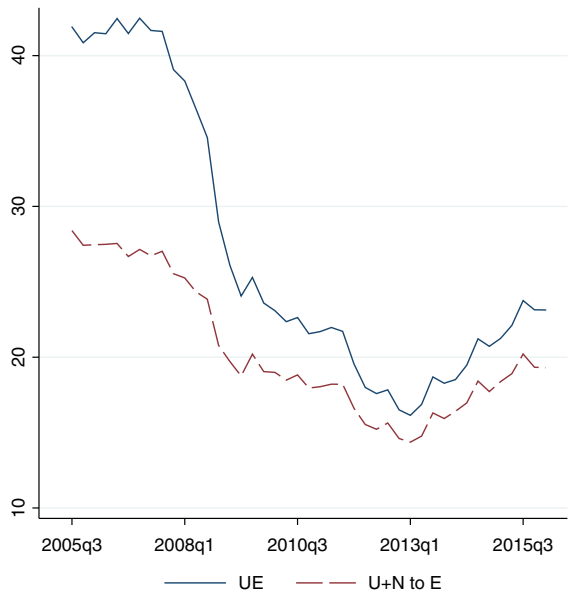

(b)

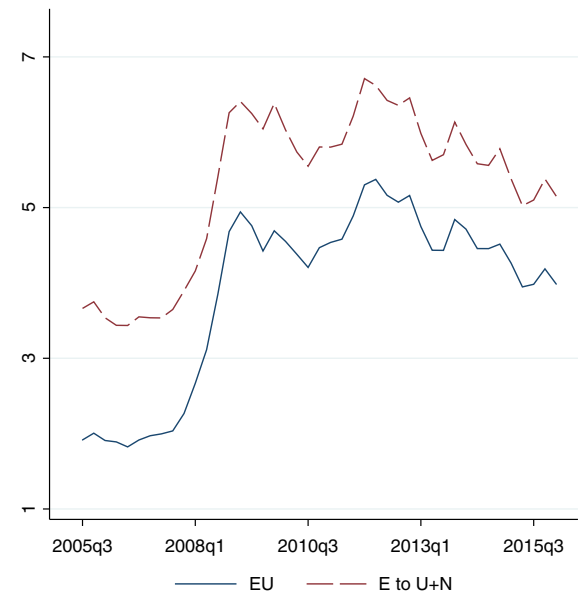

Fig. 7 Quarterly flow rates into employment and unemployment in Spain, 2005Q3-2016Q3 (\%) a Into employment, b Out of employment. Note Rates are computed with respect to the reference population in the preceding quarter. Source: INE, Encuesta de Población Activa

reveal that the dividing line between unemployment and nonparticipation is quite permeable. People without a job who stop searching for one quarter go from unemployment to nonparticipation, but if they look for work again in the following quarters they will go through the reverse transition. These transient flows are frequent, indicating that nonparticipation is not necessarily persistent, especially within this age bracket. Thus, as has been pointed out for the US by Elsby et al. (2015), flows involving nonparticipation can be a crucial element in explaining the dynamics of unemployment.

In view of this finding - and also due to data limitations - in Sect. 4 we study the transitions between nonemployment and employment. It is therefore worth checking their cyclical behavior vis-à-vis the traditional ones involving unemployment rather than nonemployment. These are represented in Fig. 7, where the left panel depicts the employment inflow rates and the right panel the employment outflow rates. It is apparent that the transition rates from and to nonemployment follow similar patterns as the traditional transition rates between employment and unemployment.

\section{What affects the probability of entering and leaving LTU?}

This section presents our empirical results on the probability of entering and exiting LTU. Our key goal is to estimate the impact of individual characteristics and duration dependence on the profile of the job-finding rates of the long-term unemployed. Throughout the analysis we control for unobserved heterogeneity to avoid potential bias due to selection on unobservables. We begin this section by explaining our empirical approach, we then move on to describe the key characteristics of the sample, and we end the section with a discussion of our main estimation results. 


\subsection{Empirical approach}

We assume that individuals move between two mutually exclusive states, employment and unemployment (or, more rigorously, nonemployment). Furthermore, in view of the dual nature of the Spanish labor market, we distinguish between temporary and permanent employment. And, since we are interested in analyzing the transitions between these labor states, our empirical model will consider the joint estimation of the exit or hazard rates out of both employment and unemployment.

We specify these hazard rates using a discrete-time duration model (Jenkins 1995), which are given by the following conditional probability:

$$
h(t)=\operatorname{Pr}(T=t \mid T \geq t)
$$

where $T$ is a discrete random variable denoting either employment or unemployment duration. The hazard $h(t)$ therefore measures the probability of a transition for a person who has remained in the same state for exactly $t$ periods. We also allow multiple destinations from each state, i.e. we employ a competing risks model for each state (Lancaster 1990).

Our framework is similar to the one in Carrasco and García-Pérez (2015) and very close to that in Rebollo-Sanz and García-Pérez (2015). The hazard rate of unemployed individuals depends on unemployment duration, $t$, and on a vector of variables $x(t)$ that includes a set of individual, sectoral, and aggregate variables described below. It also depends on the person's unemployment benefit entitlement, which is captured by two variables. The first one is a dummy variable, $b(t)$, that takes the value one when the worker is receiving an unemployment subsidy in period $t$. The second one is a discrete variable $e(t)$ that captures the remaining months of entitlement for persons who are eligible to contribution-based unemployment benefits and are receiving them. These two benefits variables and some variables in $x(t)$ are allowed to have heterogeneous effects over the unemployment spell through their time-varying coefficients, $\alpha_{i}(t)$, which feature an interaction with $\log$ duration. In the case of $e(t)$ this is modeled by allowing $\alpha_{3}(t)$ to be a cubic polynomial in log duration. ${ }^{10}$ Accordingly, the unemployment hazard rate has the following structure:

$$
\begin{aligned}
h_{u}^{j}(t) & =\operatorname{Pr}\left(T_{u}=t \mid T_{u} \geq t, x(t), b(t), e(t), \eta^{u}\right) \\
& =F\left(\alpha_{0}^{j}(t)+\alpha_{1}^{j}(t) x(t)+\alpha_{2}^{j}(t) b(t)+\alpha_{3}^{j}(t) e(t)+\eta^{u}\right)
\end{aligned}
$$

where $j=e_{T}, e_{P}$ denotes, respectively, the two alternative exits from unemployment, i.e. employment with a temporary contract and with a permanent contract, as in Bover and Gómez (2004). The last term in the formula captures time-invariant unobserved heterogeneity and is discussed below.

The exit from employment is also estimated using a competing risks model and all coefficients in these hazard rates are allowed to differ between temporary and permanent employees. The two competing risks for employed workers are moving to

$\overline{10}$ This is a departure from Rebollo-Sanz and García-Pérez (2015), who assume linearity. 
another job, $e$, without going through unemployment, and moving to unemployment, $u$. Hence, the employment hazard rate has the following specification:

$$
h_{e}^{k}(t)=\operatorname{Pr}\left(T_{e}=t \mid T_{e} \geq t, x(t), \eta^{e}\right)=F\left(\beta_{0}^{k}(t)+\beta_{1}^{k}(t) x(t)+\eta^{e}\right)
$$

where $k=e, u$. This hazard rate is simpler than the one in Rebollo-Sanz and GarcíaPérez (2015), where it also depends on previous receipt of unemployment benefits. The variables in $x(t)$ are the same as in the unemployment hazard.

Following Bover et al. (2002) and García-Perez and Muñoz-Bullón (2011), we use a logistic distribution to model all hazard rates. ${ }^{11}$ Moreover, as we are considering competing risks models for both employment and unemployment, exit from a given state needs to be specified as a multinomial logit model with two alternative risks for each state:

$$
\begin{aligned}
& h_{u}(t)=h_{u}^{e_{T}}(t)+h_{u}^{e_{P}}(t) \\
& h_{e}(t)=h_{e}^{e}(t)+h_{e}^{u}(t)
\end{aligned}
$$

Lastly, in order to avoid spurious duration dependence in the hazard rate generated by the presence of unobserved factors (van den Berg 2001), we control for unobserved heterogeneity affecting the flows both to and from unemployment. This is captured by the terms $\eta^{u}$ and $\eta^{e}$ in the expressions for the hazards. We exploit the fact that we observe multiple spells for the same individual and we estimate the unemployment and employment hazard rates simultaneously, assuming that unobserved heterogeneity follows a discrete distribution function with different mass points, as in Heckman and Singer (1984). In particular, we allow a four-mass-point distribution function, namely two different points for each state, $\eta_{1}^{u}$ and $\eta_{2}^{u}$ for unemployment, and $\eta_{1}^{e}$ and $\eta_{2}^{e}$ for employment, so that four different types may emerge with joint probabilities, namely: $\left(\eta_{1}^{u}, \eta_{1}^{e}\right),\left(\eta_{1}^{u}, \eta_{2}^{e}\right),\left(\eta_{2}^{u}, \eta_{1}^{e}\right)$, and $\left(\eta_{2}^{u}, \eta_{2}^{e}\right)$. Standard errors for the estimated coefficients are computed using the delta method. The existence of repeated employment and unemployment spells and, more importantly, of some time-varying covariates allows non-parametric identification (Abbring and van den Berg 2004; Gaure et al. 2007).

Before presenting the results it is worth noting that our empirical approach only yields reduced-form estimates, resulting from the interplay of labor demand and supply, so that they do not have a causal interpretation. They are nevertheless informative on the characteristics which are associated with a higher risk of LTU.

\subsection{The sample and the set of control variables}

Our initial data set is a $20 \%$ random sample of the prime age males aged 25-54 whose records appear in the nine waves of the Continuous Sample of Working Lives (Muestra Continua de Vidas Laborales or MCVL) corresponding to the period 20062014. All individuals must have experienced at least one spell of nonemployment

\footnotetext{
11 We could have alternatively used the extreme value distribution. As explained in van den Berg (2001), this distribution allows the model to verify the mixed proportional hazard assumption. Our approach departs from the proportionality assumption, at the cost of imposing more structure, because we want to allow the potential impact of duration and of both observed and unobserved heterogeneity on the exit from employment and unemployment not to be proportional.
} 
between 2001 and 2014. Individuals only appear in the records when they pay Social Security contributions - roughly, if they are either employed or nonemployed and receiving unemployment benefits. No information about job search activity is available in the data set, hence we cannot distinguish between unemployed and nonparticipating individuals. Moreover, nonemployed individuals drop out of the records if they stop receiving benefits. This is however not a problem, since the length of completed spells of nonemployment can be reconstructed using the information on the subsequent job. Furthermore, to exclude persistent nonparticipantion, we limit nonemployment duration to 3 years, after which spells are treated as censored. With this caveat in mind, as already indicated, we take the license of referring to individuals without employment as unemployed rather than as nonemployed.

Against this potential drawback, the MCVL data have crucial advantages vis-àvis the flow data from the LFS. They allow us to follow workers since the start of their working careers - whereas the LFS only follows individuals for six quartersand they have a daily frequency, which permits the observation of all employment spells-while many labor market transitions are missed in the LFS due to its quarterly frequency. We can also construct a worker's entitlement to benefits from the MCVL, whereas the LFS only allows us to know whether the worker is receiving benefits or not. By contrast, using this data source implies that we do not have any information on people living in the same household as the unemployed worker, such as their labor status, which is available in the LFS.

In order to avoid problems concerning attrition, we only analyze employment spells in the general Social Security regime, thus excluding special regimes such as agriculture, public employment, and self-employment, and treat exits from unemployment to these states as right-censored (García Pérez 2008). Moreover, in the case of workers who are recalled to the same firm, a feature which has become increasingly important in Spain (Arranz and García-Serrano 2014), we only consider intervening unemployment spells lasting more than 30 days. ${ }^{12}$ Lastly, to maximize the probability of observing the individual's complete work history, we exclude both immigrants and people who appear for the first time in the sample being 30 years old or older (because may have an unrecorded work history).

Our set of control variables includes both individual characteristics and aggregate variables. The former comprise: (a) Age, grouped into three 10-year intervals. (b) Education, measured by dummy variables for the highest degree attained. ${ }^{13}$ (c) Skill, divided into high, medium, and low, computed from grouped Social Security tax categories. ${ }^{14}$ (d) Actual experience, measured by the number of months employed

\footnotetext{
12 Accordingly, two employment spells with the same firm which have an intervening unemployment spell below 30 days are treated as a single employment spell.

13 The data on educational attainment in the MCVL is officially revised using information from the Spanish Continuous Census of Population (Padrón Continuo). It has however been improved since 2009 with data from the Ministry of Education, and so we use the latter information, imputing it backwards (see De la Roca and Puga 2016, footnote 7).

14 High skill includes college and junior college graduates, and top and middle managers (groups 1 to 6 in the Social Security classification), medium skill includes administrative assistants and so-called firstand second-level officers (groups 7 and 8), and low skill includes third-level officers and unskilled workers (groups 9 and 10), see García Pérez (1997).
} 
divided by the number of months of potential experience (i.e. those elapsed since the person entered the labor market). (e) A dummy variable that captures whether the worker was fired from his previous job. And (f) our controls for benefit entitlement. As explained before, contributory benefits are measured by the remaining months of entitlement in each month (Meyer 1990). The latter is computed from each individual's employment and insurance claim history (since residual benefits not claimed in one unemployment spell can be claimed in a later spell). ${ }^{15}$ This entitlement is entered as a cubic polynomial in order to capture nonlinear effects.

The aggregate variables included in the model are as follows: (a) Employment growth, defined as the monthly growth rate of the number of employees by province. (b) The quarterly national unemployment rate. (c) 17 region dummies. (d) 6 industry dummies. (e) 12 monthly dummies. And (f) two step dummy variables for the labor reforms in June 2010 and February 2012, that take the value one from those dates onwards.

Finally, the following variables are interacted with log duration: age, education, skill, unemployment insurance (linear and quadratic), unemployment assistance, employment growth, national unemployment rate, and industry. In an extension we also interact the type of contract (see below).

\subsection{Descriptive statistics}

Table 3 shows the main characteristics of workers in the sample when they enter unemployment, separately for the expansion (2001-2007) and the recession (20082014). It should be stressed that they correspond to workers involved in inflows rather than to worker stocks. The majority are younger than 35 years old, have completed at most compulsory secondary education, and enter unemployment from a temporary job. These facts confirm our previous remarks regarding Table 1, which is based on LFS data. The education breakdown matches well the skill structure measured via occupations. In the expansion, close to one-half of the unemployed do not qualify for benefits. There are sizeable changes in the composition of inflows from expansion to recession, with workers becoming on average younger and less educated. They are also more likely to have been dismissed (as quits fall) and to come from permanent jobs. Accordingly, they are more likely to be entitled to unemployment benefits. The share of construction workers falls, which may seem surprising, but this simply reflects a reduction in turnover in that industry, given the scarcity of new jobs. ${ }^{16}$

Next, Table 4 presents some descriptive statistics of spells. The vast majority (91\%) of non-censored exits from unemployment are to temporary jobs, but the average length is similar for spells ending in both types of contracts. ${ }^{17}$ Completed spells are quite

\footnotetext{
15 Workers having access to two different sets of benefit entitlements must choose between them. We assume that they choose the one with the higher length. For more information see Rebollo-Sanz and García-Pérez (2015).

16 According to the LFS, flows into construction from nonemployment were in 2014 equal to one-third of the level in 2008.

17 Overall, $18.4 \%$ of spells are censored, which correspond to true censoring (13.3\%) and exit after 36 months (5.1\%).
} 
Table 3 Descriptive statistics of worker characteristics, 2001-2014 (\%)

\begin{tabular}{|c|c|c|c|c|}
\hline & \multicolumn{2}{|c|}{ Expansion } & \multicolumn{2}{|c|}{ Recession } \\
\hline & Mean & SD & Mean & SD \\
\hline \multicolumn{5}{|l|}{ Age } \\
\hline 25-34 years old & 88.3 & $(32.2)$ & 60.7 & $(48.8)$ \\
\hline 35-49 years old & 10.7 & $(30.9)$ & 35.6 & $(47.9)$ \\
\hline 45-54 years old & 1.0 & $(10.1)$ & 3.7 & $(19.0)$ \\
\hline \multicolumn{5}{|l|}{ Education } \\
\hline Primary or less & 11.9 & $(32.3)$ & 13.5 & $(34.2)$ \\
\hline Secondary, 1st stage & 48.7 & $(50.0)$ & 51.0 & $(50.0)$ \\
\hline Secondary, 2nd stage & 25.3 & $(43.5)$ & 23.2 & $(42.2)$ \\
\hline College & 14.2 & $(34.9)$ & 12.3 & $(32.8)$ \\
\hline \multicolumn{5}{|l|}{ Skill } \\
\hline High & 31.1 & $(46.3)$ & 41.4 & $(49.3)$ \\
\hline Low & 24.7 & $(43.1)$ & 11.6 & $(32.0)$ \\
\hline Medium & 44.2 & $(49.7)$ & 47.0 & $(49.9)$ \\
\hline \multicolumn{5}{|l|}{ Experience } \\
\hline Fraction of potential & 76.9 & $(25.7)$ & 77.3 & $(24.6)$ \\
\hline \multicolumn{5}{|c|}{ Dismissal from previous job } \\
\hline Dismissed & 80.8 & $(39.4)$ & 91.5 & $(27.9)$ \\
\hline Not dismissed & 19.2 & $(39.4)$ & 8.5 & $(27.9)$ \\
\hline \multicolumn{5}{|l|}{ Industry of previous job } \\
\hline Manufacturing & 13.6 & $(34.2)$ & 12.7 & $(33.3)$ \\
\hline Construction & 29.6 & $(45.7)$ & 25.7 & $(43.7)$ \\
\hline Non-market services & 7.5 & $(26.3)$ & 9.5 & $(29.3)$ \\
\hline Trade & 11.4 & $(31.7)$ & 11.5 & $(31.8)$ \\
\hline Hospitality & 9.1 & $(28.8)$ & 11.4 & $(31.8)$ \\
\hline Other services & 28.9 & $(45.3)$ & 29.3 & $(45.5)$ \\
\hline \multicolumn{5}{|l|}{ Unemployment benefits } \\
\hline Contributory & 26.2 & $(44.0)$ & 29.0 & $(45.4)$ \\
\hline Assistance & 17.7 & $(38.2)$ & 35.6 & $(47.9)$ \\
\hline No benefits & 56.1 & $(49.6)$ & 35.3 & $(47.8)$ \\
\hline \multicolumn{5}{|c|}{ Previous job contract type } \\
\hline Permanent & 16.4 & $(37.0)$ & 20.3 & $(40.3)$ \\
\hline Temporary & 83.6 & $(37.0)$ & 79.7 & $(40.3)$ \\
\hline Number of spells & 37,399 & & 62,045 & \\
\hline
\end{tabular}

The sample is made up of males aged 25-54 years old. The expansion corresponds to the period 20012007 and the recession to 2008-2014. The characteristics correspond to individuals in their first month in unemployment. Columns add up to 100 by characteristic

lengthy, around 5 months on average in the expansion and 6 months in the recession, though - as shown for the third quartile - they are much lengthier in the upper tail of the distribution. Moreover, the recession is characterized by a strong rise in both 
Table 4 Unemployment duration, benefit duration, and raw hazard rates

\begin{tabular}{|c|c|c|}
\hline & Expansion & Recession \\
\hline \multicolumn{3}{|c|}{ A. Unemployment duration (months) } \\
\hline \multicolumn{3}{|c|}{ Exit to a temporary job } \\
\hline Median & 3.0 & 4.0 \\
\hline Third quartile & 6.0 & 8.0 \\
\hline Mean & 4.5 & 6.3 \\
\hline Share of spells (\%) & 76.6 & 69.9 \\
\hline \multicolumn{3}{|l|}{ Exit to a permanent job } \\
\hline Median & 3.0 & 4.0 \\
\hline Third quartile & 6.0 & 8.0 \\
\hline Mean & 5.1 & 6.2 \\
\hline Share of spells (\%) & 7.9 & 8.1 \\
\hline \multicolumn{3}{|l|}{ Censored spells } \\
\hline Median & 5.0 & 8.0 \\
\hline Third quartile & 11.0 & 16.0 \\
\hline Mean & 7.6 & 10.7 \\
\hline Share of spells $(\%)$ & 15.5 & 22.0 \\
\hline \multicolumn{3}{|c|}{ B. Unemployment benefit duration (months) } \\
\hline \multicolumn{3}{|c|}{ All } \\
\hline Median & 7.0 & 10.0 \\
\hline Mean & 9.8 & 11.2 \\
\hline \multicolumn{3}{|l|}{ Temporary previous job } \\
\hline Median & 6.0 & 8.0 \\
\hline Mean & 8.9 & 10.0 \\
\hline \multicolumn{3}{|l|}{ Permanent previous job } \\
\hline Median & 16.0 & 20.0 \\
\hline Mean & 15.6 & 16.8 \\
\hline \multicolumn{3}{|c|}{ C. Hazard rates out of unemployment (\%) } \\
\hline \multicolumn{3}{|c|}{ Exit to a temporary job } \\
\hline No benefits & 16.9 & 9.3 \\
\hline Contributory benefits & 9.7 & 7.2 \\
\hline Assistance benefits & 11.3 & 7.9 \\
\hline \multicolumn{3}{|l|}{ Exit to a permanent job } \\
\hline No benefits & 1.6 & 1.0 \\
\hline Contributory benefits & 1.3 & 1.2 \\
\hline Assistance benefits & 1.2 & 0.7 \\
\hline Number of spells & 37,399 & 62,045 \\
\hline
\end{tabular}

The sample is made up of males aged 25-54 years old. The expansion corresponds to the period 2001-2007 and the recession to 2008-2014. Shares of spells add to 100 by column 


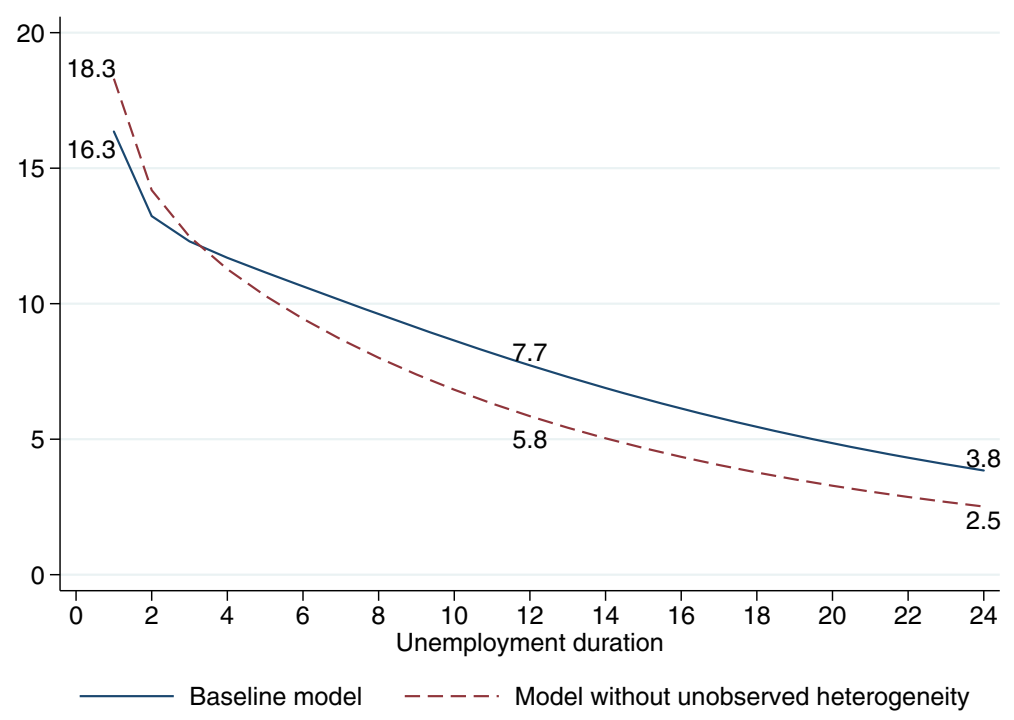

Fig. 8 Duration dependence in the baseline model and the model without unobserved heterogeneity (\%). Source: own computations

the share and the duration of censored spells. Average benefit entitlement periods last 10-11 months, but they are much smaller for workers coming from temporary jobs than from permanent jobs, the latter having a mean around 17 months in the recession. Lastly, average monthly hazard rates are typically smaller for workers who receive unemployment benefits and the rates from unemployment to permanent jobs are around one-tenth of those to temporary jobs.

\subsection{Baseline empirical results}

We now present our estimation results. In order to save space we restrict our attention to the hazard of leaving unemployment (the estimates for the hazard of leaving employment are reported in Bentolila et al. 2017).

\subsubsection{Hazards}

The hazard rate for the recession is shown in Fig. 8. It corresponds to a hypothetical individual with the average characteristics in our sample and it takes into account all interactions between worker characteristics and duration. The underlying estimated coefficients are reported in Table 8 in the Appendix.

The decay in the average hazard rate provides our best estimate of the magnitude of duration dependence. ${ }^{18}$ During the first 12 months of unemployment, the monthly hazard of the average individual drops by $53 \%$ or equivalently by $8.6 \mathrm{pp}$ (from 16.3 to

\footnotetext{
18 The identification of duration dependence in hazard models remains a highly-debated topic, see Machin and Manning (1999).
} 
$7.7 \%$ ) and it halves again during the second year (from 7.7 to $3.8 \%$ ). This is a sizable effect. To get an idea of the relative size of duration dependence, let us compare it with the effects of other variables on the hazard rate in the initial month of unemployment, all computed for the average worker. In month 1, the average worker with no benefits has a hazard rate of $23.5 \%$ whereas a worker with a 12 -month entitlement to contributory benefits has a hazard rate of $9.1 \%$, i.e. a 14.4 pp difference. Thus the $8.6 \mathrm{pp}$ fall in the hazard rate over the first 12 months induced by duration dependence represents $60 \%$ of this difference. Similarly, the initial hazard rate for an average worker with a 24-month entitlement is equal to $4.3 \%$, which implies a 19.2 pp difference vis-à-vis the same worker with no benefits. The $8.6 \mathrm{pp}$ hazard rate reduction found for duration dependence therefore amounts to $45 \%$ of this difference. Moreover, the impact of duration dependence is also much higher than the $5.6 \mathrm{pp}$ difference implied by the movement from the 25 th to the 75 th percentile in the distribution of actual work experience and than the meager $2.8 \mathrm{pp}$ difference between the initial hazard rates of 25-34 year-old workers and 45-54 year-old ones.

Figure 8 also confirms the need to control for unobserved heterogeneity. Failure to do so biases the estimation of duration dependence upwards, as indicated by the steeper curve, which depicts the average hazard for our baseline model in that case (and which now falls by $68 \%$, from 18.3 to $5.8 \%$, during the first year). The estimates related to unobserved heterogeneity appear in Table 9 in the Appendix. While their interpretation is not straightforward, it is still worth to briefly comment them. According to our results, there are two prevailing types of workers: the $\left(\eta_{\text {high }}^{u}, \eta_{\text {low }}^{e}\right)$ type, i.e. those with a strong labor-market attachment, who leave unemployment fast and employment slowly (32\% of the individuals in the expansion), and the $\left(\eta_{\text {low }}^{u}, \eta_{\text {low }}^{e}\right)$ type, i.e. those who leave both unemployment and employment slowly (50\% of the individuals). The observed changes in the shares from the expansion to the recession indicate that part of the increase in unemployment duration is due to a fall in the share of fast unemployment leavers (by $13 \mathrm{pp}$ ) and the offsetting increase in slow leavers, especially among those with low exit rates from both unemployment and employment.

\subsubsection{The predicted probability of entering LTU or VLTU}

Both the initial hazard rate and the slope of the hazard function differ across individuals. In order to assess the marginal impact of individual characteristics on the probability that a worker enters LTU or VLTU, we report in Table 5 the survival rates in unemployment at 12 and 24 months - i.e. the probability that an individual does not manage to find a job during the first or second year of unemployment. Apart from the average survival rates reported in the top row, these rates are constructed by varying one characteristic at a time and setting all other characteristics to the values used to compute the average hazard rates. Moreover, in order to construct the survival rates at 24 months we have rescaled the survival rate at 12 months to 100 . It therefore measures the conditional probability that an individual who is still unemployed after 1 year remains unemployed for 12 more months.

Inspection of the table reveals that the chances of entering LTU have almost doubled in recent years, as indicated by the rise in the survival rate at 12 months from $13.8 \%$ in the expansion to $25.5 \%$ in the recession. The difficulty to escape LTU is captured by the 
Table 5 Survival rates in unemployment at 12 and 24 months (\%)

\begin{tabular}{|c|c|c|c|c|}
\hline & \multicolumn{2}{|l|}{ Expansion } & \multicolumn{2}{|l|}{ Recession } \\
\hline & 12 months & 24 months & 12 months & 24 months \\
\hline Overall & 13.8 & 33.2 & 25.5 & 51.3 \\
\hline \multicolumn{5}{|l|}{ Age } \\
\hline 25-34 years old & 13.3 & 32.2 & 23.7 & 48.9 \\
\hline $35-44$ years old & 16.0 & 38.6 & 27.5 & 53.9 \\
\hline 45-54 years old & 27.5 & 49.8 & 34.9 & 62.9 \\
\hline \multicolumn{5}{|l|}{ Education } \\
\hline Primary or less & 13.4 & 31.0 & 28.4 & 51.8 \\
\hline Secondary, 1st stage & 11.2 & 27.7 & 24.2 & 47.1 \\
\hline Secondary, 2nd stage & 14.7 & 32.0 & 26.6 & 50.8 \\
\hline College & 19.6 & 35.9 & 27.6 & 50.7 \\
\hline \multicolumn{5}{|l|}{ Skill } \\
\hline High & 14.9 & 36.0 & 26.0 & 52.6 \\
\hline Medium & 12.5 & 31.6 & 23.4 & 49.0 \\
\hline Low & 14.5 & 31.9 & 30.7 & 54.0 \\
\hline \multicolumn{5}{|l|}{ Experience } \\
\hline P75 & 10.7 & 28.3 & 18.5 & 43.4 \\
\hline P50 & 12.2 & 30.7 & 22.3 & 47.9 \\
\hline $\mathrm{P} 25$ & 16.2 & 36.6 & 30.8 & 56.5 \\
\hline $\mathrm{P} 10$ & 20.6 & 42.2 & 40.6 & 64.9 \\
\hline \multicolumn{5}{|l|}{ Industry } \\
\hline Manufacturing & 12.3 & 30.0 & 23.7 & 47.3 \\
\hline Construction & 11.8 & 31.8 & 23.6 & 48.3 \\
\hline Non-market services & 18.4 & 39.7 & 30.9 & 58.3 \\
\hline Trade & 14.8 & 30.6 & 27.7 & 50.2 \\
\hline Hospitality & 12.3 & 27.5 & 22.1 & 46.8 \\
\hline Other services & 14.7 & 36.2 & 25.7 & 54.7 \\
\hline \multicolumn{5}{|l|}{ Unemployment insurance } \\
\hline No benefits & 5.7 & 19.9 & 12.1 & 36.0 \\
\hline 6 months & 13.0 & 19.9 & 20.6 & 36.0 \\
\hline 12 months & 35.0 & 19.9 & 41.9 & 36.0 \\
\hline 18 months & 45.3 & 30.9 & 52.6 & 46.9 \\
\hline 24 months & 53.3 & 56.1 & 60.7 & 65.6 \\
\hline \multicolumn{5}{|c|}{ Unemployment assistance } \\
\hline No & 5.7 & 19.9 & 12.1 & 36.0 \\
\hline Yes & 31.3 & 51.7 & 44.3 & 67.3 \\
\hline \multicolumn{5}{|l|}{ Business cycle } \\
\hline High growth & 12.6 & 30.7 & 22.2 & 49.5 \\
\hline Low growth & 15.2 & 35.8 & 28.4 & 52.6 \\
\hline
\end{tabular}

The sample is made up of males aged 25-54 years old. The expansion corresponds to the period 2001-2007 and the recession to 2008-2014. The probability for the 24th month is computed after resetting it to 100 at 12 months 
survival rate at 24 months. In the expansion two-thirds of the long-term unemployed managed to leave unemployment in the next 12 months, but in the recession this figure dropped to one-half. Hence, the recent recession is characterized by a strong rise in the inflow rate to LTU and a substantial drop in the outflow rate, leading to a higher incidence and a stronger persistence of LTU.

In line with our previous results, we find that individuals over 45 years old are especially prone to enter LTU, with estimated survival probabilities at 12 and 24 months in the recession of, respectively, 35 and $63 \%$. The vulnerability of these workers is not a new situation, however, as the survival probabilities for this group were also quite high in the expansion. Given our controls for other worker characteristics, this finding points at structural problems for older workers in rebuilding their working careers after job loss.

In the case of education we find surprisingly small and non-monotonic effects. For the expansion, we find a U-shaped pattern in the relation between education and the survival rate. The individuals with at most mandatory education enjoy the lowest survival rates while college graduates face the largest ones. The difference in survival rates is around $8 \mathrm{pp}$. This counterintuitive result is likely due to the relatively intensive growth of low-skilled jobs during the expansion, which was fueled by the housing boom (Bonhomme and Hospido 2017). Indeed, for the recession period, characterized by a steep drop in the demand for low-skill labor, the differences across all educational attainment groups are much smaller. For example, the difference in the chances of becoming long-term unemployed between college and compulsory education graduates is reduced to $3 \mathrm{pp}$. The U-shaped relationship is also present for our occupation-based measure of skill, with less skilled workers showing higher survival rates in the recession. Apart from labor demand, another factor underlying this finding could be that higher job opportunities for more skilled workers are hampered by their higher reservation wages. On the other hand, in our companion estimation of employment hazards we do find that more educated and more skilled workers have significantly longer employment durations (Bentolila et al. 2017).

Table 5 reveals that higher work experience does significantly reduce the chances of becoming long-term unemployed. Moving from the 10th to the 75th percentile of the distribution of actual work experience reduces the survival rate at 12 months by around $50 \%$ in both the expansion and the recession.

As expected, we find that workers from construction have the lowest survival rate (at 12 months) in the expansion. What is somewhat more surprising is that they still enjoy the second-lowest survival rates in the recession, despite the bursting of the housing bubble. The explanation for this finding seems to be the comparatively high degree of turnover in construction. Almost $60 \%$ of jobs in this industry last up to 3 months, compared to $44 \%$ for the other industries. Thus, short-duration temporary contracts seem to act as an informal work-sharing arrangement, allowing a relatively large share of unemployed construction workers to find work and thus avoid entering LTU. The alternative explanation of a high degree of occupational mobility is not supported by the data. Indeed, inspection of post-unemployment outcomes reveals that unemployed construction workers are less likely to take up jobs in a different 


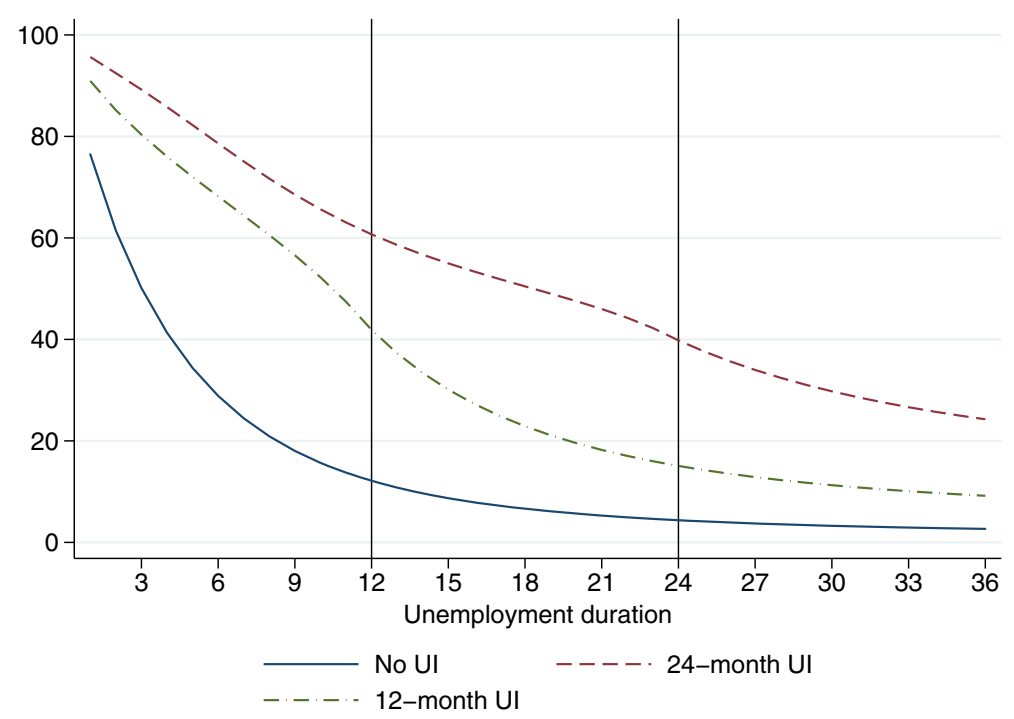

Fig. 9 Effect of unemployment insurance (UI) on the survival rate in unemployment (\%). Source: own computations

industry than workers from the other industries. And those who do mostly relocate to non-knowledge intensive service industries (see Jansen et al. 2016 for details). ${ }^{19}$

At first blush these results may seem inconsistent with the fact that almost $20 \%$ of the very long-term unemployed used to work in construction (see Table 2). However, it should be recalled that this industry made up around $13 \%$ of total employment before the crisis and, contrary to our initial descriptive analysis, we are now controlling for worker characteristics. The prevalence of high-school dropouts and other unfavorable characteristics among construction workers shows up in low average exit rates, but differences with other industries become much less hampering once we control for those characteristics.

The largest adverse effects on unemployment exit rates are associated with the receipt of unemployment benefits. ${ }^{20}$ As shown in Fig. 9, during the recession a worker with a 12-month entitlement to contributory benefits has an almost $42 \%$ chance of entering LTU. By contrast, for a similar worker with no benefits this probability is 30 pp lower. Analogously, conditional on having entered LTU, a 24-month benefit entitle-

19 In connection with this issue, Lacuesta et al. (2012) downplay the implications of the employment sectoral change for the job-finding chances of the unemployed in Spain. They argue that in spite of the high degree of sectoral reallocation of employment stemming from the crisis, the degree of similarity between the occupations that the unemployed had in their previous job and those of the employed-or indeed of new vacancies - is high when compared with other European countries, and that this similarity has not fallen much during the crisis.

20 Large effects of unemployment benefits on unemployment duration have been found in many articles, like those cited regarding Spain in Sect. 2. Recent research has moved towards exploiting natural experiments, see Moffit (2014) for an overview. For Spain, Rebollo-Sanz and Rodríguez-Planas (2016) have found a strong impact on the job-finding probability of the reduction in the benefit replacement rate that took place in Spain in 2012. 
ment raises the probability of entering VLTU by a further 30 pp vis-à-vis a comparable worker without UI benefits $(0.656-0.36)$, or 35 pp unconditionally $(0.607 \times 0.656-$ $0.121 \times 0.36) .{ }^{21}$ In terms of entry into LTU, the effect for a worker without benefits of getting just a 6-month UI entitlement is larger than the effect of the economy moving from expansion to recession-namely, from 5.7 to $13 \%$ in the first column versus going from 5.7 to $12.1 \%$ in the third column. And much higher differences are found for higher entitlement lengths. The size of the change in the survival rate attached to unemployment assistance benefits is similar. These differences in survival rates suggest that workers with unemployment benefits either exert a relatively low search effort and/or have a high reservation wage. Then, when they step up their effort to find a job upon the upcoming expiry of their benefits, they are affected by strong duration dependence, and so at that point their chances of leaving unemployment are much lower than at the start of their unemployment spell. In connection with this issue, in Sect. 5 we take a look at self-reported reservation wages.

In sum, we find that the probabilities of entering LTU and VLTU are large and that they increased significantly in the recession. The determinants of both states are quite similar and we obtain evidence of strong duration dependence. While individual characteristics like educational attainment and skill are not associated with large changes in the rate of exit from unemployment, there are larger changes attached to mature age, low experience, and receipt of unemployment benefits. ${ }^{22}$ The latter finding points at the absence of active labor market policies.

\subsubsection{The business cycle and unemployment duration}

How does the business-cycle impact on hazard rates vary by workers' unemployment duration? To answer this question we have computed the average hazard rate in the recession in two scenarios. The bad scenario is one in which provincial employment growth is set at its first quartile and the national unemployment rate at its third quartile in this period $(-4.8$ and $25.1 \%$, respectively), while in the good scenario each variable is set at the opposite quartile (third and first, with respective values of -0.4 and $18.6 \%$ ).

As can be seen in Fig. 10, the predicted hazard rates for unemployment durations of 1,12 , and 24 months in the low-growth and the high-growth scenarios, respectively, are: 14.5 versus $18.6,7.3$ versus 8.2 , and 3.7 versus 4.0 . In other words, upon an improvement in the labor market, those who have been unemployed for 1 month leave $28.3 \%$ faster, those unemployed for 1 year leave $12.3 \%$ faster, and those unemployed for 24 months leave only $8.1 \%$ faster. These figures clearly illustrate that a cyclical upturn helps the long-term unemployed very little and confirm the evolution of relative exit rates by duration that were previously shown in Fig. 5. Our estimates imply that growth alone will not suffice to significantly push the long-term unemployed back into

\footnotetext{
21 Note that the rates of survival to 24 months shown in the table are the same for all benefit entitlements up to 12 months since, by construction, upon exhaustion of their benefits the monthly hazard rate for workers with UI benefits converges to the hazard rate for workers without benefits.

22 Several of these results are common to Nagore and van Soest (2016b), who analyze unemployment exits during the crisis using the same data source but different samples and methods.
} 


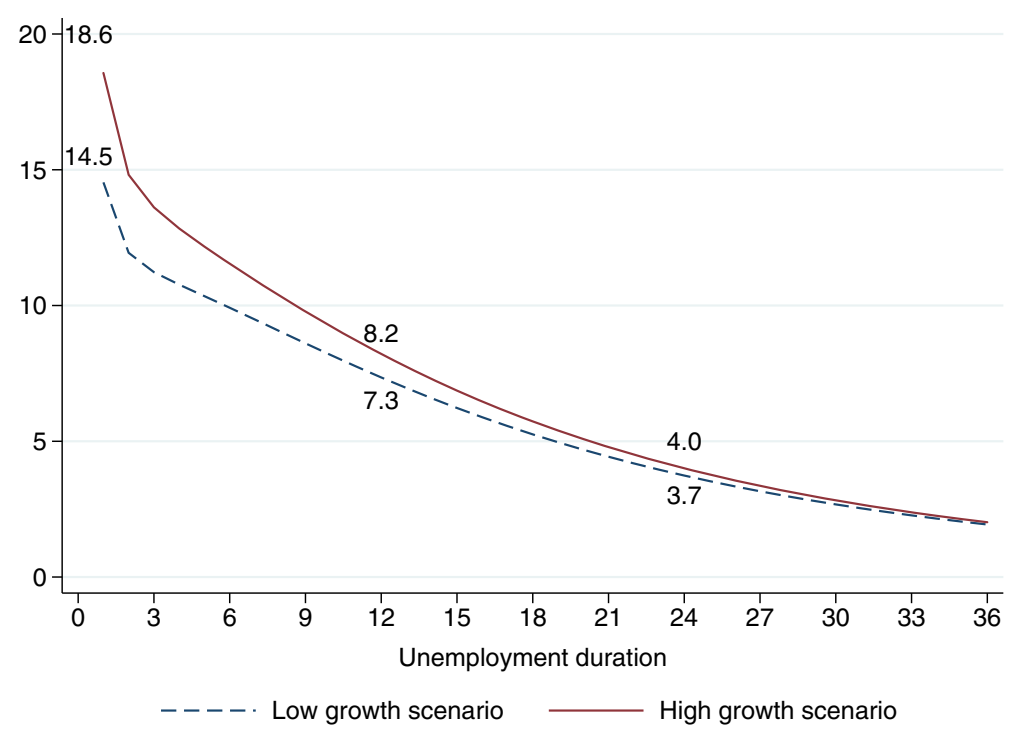

Fig. 10 Effect of the business cycle on the hazard rates by unemployment duration (\%). Source: own computations

jobs and this fact entails a substantial risk of social and economic exclusion of these people unless effective labor market policies to reenfranchise them are implemented.

\subsection{Alternative empirical specifications}

Given the prevalence of temporary labor contracts in Spain, many of the jobs that unemployed workers find are very short-term. We may therefore wonder what types of workers mostly benefit from the availability of short-duration jobs and whether these jobs act as stepping-stones to more stable employment. One way to look at this issue is to treat exits from unemployment to employment spells that last up to 30 days as right-censored rather than as standard exits. ${ }^{23}$ We can then examine the resulting changes in the estimated coefficients associated with worker characteristics, which we again do through the lens of survival rates to 12 and 24 months in unemployment.

The full results are reported in Table 10 in the Appendix, while the most relevant changes are presented in Table 6. By construction, the average survival rates turn out to be larger than in the baseline, by 17.4 and $14.5 \mathrm{pp}$, respectively, for LTU and VLTU. But the important point is that the effect of ignoring short-duration employment spells varies significantly across population groups. To see this, note that the increase in the LTU rate for college graduates is $6.7 \mathrm{pp}$ less than for workers without secondary education. Similarly, the survival rate in LTU for workers at the first decile of the distribution of experience increases by $9.8 \mathrm{pp}$ more than for those at the 75 th percentile. Furthermore, in this alternative specification the estimated survival rates at both 12 and 24 months are monotonically decreasing in the educational attainment

\footnotetext{
23 We also adjust the estimation of the employment hazard accordingly.
} 
Table 6 Survival rates in unemployment at 12 and 24 months in the recession. Censored model (\%)

\begin{tabular}{lllll}
\hline & \multicolumn{2}{l}{ Survival rate } & & \multicolumn{2}{l}{ Change versus baseline } \\
\cline { 2 - 5 } & 12 months & 24 months & 12 months & 24 months \\
\hline Overall & 42.9 & 65.7 & 17.4 & 14.5 \\
Education & & & & \\
Primary or less & 47.6 & 67.8 & 19.2 & 16.0 \\
Secondary, 1st st. & 42.7 & 63.6 & 18.5 & 16.5 \\
Secondary, 2nd stage & 42.8 & 64.0 & 16.3 & 13.2 \\
College & 40.1 & 61.4 & 12.5 & 10.7 \\
Experience & & & & \\
P75 & 31.4 & 56.0 & 13.0 & 12.6 \\
P50 & 37.8 & 61.6 & 15.5 & 13.8 \\
P25 & 50.7 & 71.6 & 19.9 & 15.1 \\
P10 & 63.4 & 80.0 & 22.7 & 15.1 \\
Unemployment insurance & & & & \\
No benefits & 28.3 & 53.4 & 16.2 & 17.5 \\
6months & 36.4 & 53.4 & 15.7 & 17.5 \\
12 months & 54.8 & 53.4 & 12.9 & 17.5 \\
18 months & 63.7 & 61.8 & 11.0 & 15.0 \\
24 months & 71.4 & 75.5 & 10.7 & 9.9 \\
Unemployment assistance & & & & 17.5 \\
No & 28.3 & 53.4 & 16.2 & 9.3 \\
Yes & 59.5 & 76.6 & 15.1 & \\
\hline
\end{tabular}

The sample is made up of males aged 25-54 years old. The recession corresponds to the period 2008-2014. The probability for the 24 th month is computed after resetting it to 100 at 12 months. The last two columns report the change in the survival rate in pp vis-à-vis the baseline estimates given in Table 5

of the unemployed. These results indicate that the somewhat counterintuitive U-shape pattern of the survival rates in our baseline specification is a reflection of the rotation of relatively low-skilled and inexperienced workers on short-duration contracts of less than a month.

One objective of future labor market reforms should be to improve access to stable jobs, especially for workers at the bottom of the skill distribution. This may require restrictions on the use of temporary contracts, but policymakers should take into account that such a policy might have adverse effects on the current long-term unemployed. A short-duration temporary contract may be the only viable option after years of unemployment and in some cases such spells may improve the subsequent jobfinding rates of the long-term unemployed. The latter issue is extremely important for policy purposes, but an analysis of the causal impact of short-duration spells on the subsequent job-finding rates of the long-term unemployed is left for future research, as it requires different techniques.

Next, in an attempt to test the robustness of our results, we have also estimated an alternative model that includes a control for the type of contract in the previous job- 
temporary or permanent-and its interaction with the linear term of UI entitlement. The objective is to minimize the possibility that our controls for benefit entitlements capture unobserved individual traits that are not captured by our controls for timeinvariant unobserved heterogeneity. For example, some workers may wish to reenter unemployment periodically once they qualify for UI benefits. These persons may be more inclined to accept temporary jobs and their propensity to exhaust their benefit entitlements is likely to be relatively strong. The estimated effects of specific worker characteristics that we find in this alternative model do indeed differ from those in our baseline specification, but in terms of the overall impact on entry to LTU or VLTU the estimates are very similar, both qualitatively and quantitatively. The largest difference appears in the effect of having a 24-month entitlement to UI benefits on the survival rate at 12 months, which is 12 pp lower in this alternative specification. ${ }^{24}$

\section{Reservation wages in the Great Recession}

Given the reduced-form nature of our estimation, we cannot distinguish between demand and supply factors. This raises the question of whether exit rates are low because labor demand is low or because the long-term unemployed have too high reservation wages. To make some progress towards answering this question, we analyze the adjustment of self-reported reservation wages during the recession.

The contents of this section are related to an ongoing debate on wage cyclicality in Spain. Real wage rigidity is well-documented to be high in Spain. ${ }^{25}$ Reentry wages after unemployment have, however, fallen considerably during the crisis and this process started as early as 2010. For example, for the prime-age males in our sample, the average reentry real wage dropped by $15.3 \%$ between 2009 and 2014 (while it grew by $5.2 \%$ between 2005 and 2009). This suggests a relatively strong adjustment in reservation wages. However, the evolution of reentry wages depends on the composition of those unemployed who regain employment and their decisions to accept job offers. Moreover, the difference between the reentry wages of the short- and long-term unemployed in our sample is very small. This could point at the need for further reductions in the reservation wages of the latter, but it might also reflect the fact that only the bestqualified long-term unemployed workers manage to find a job. For this reason, we pursue an alternative route, by analyzing the behavior of self-reported reservation wages.

\footnotetext{
24 These results are not included to save space, but they are available upon request.

25 According to the estimates with MCVL data for 1987-2013 by Font et al. (2015), a 1 pp increase in unemployment leads to a fall in real wages of $-0.24 \mathrm{pp}$ in the recession, and between -0.38 and -0.48 in the expansion. Real wage elasticity is found to be about $70 \%$ higher for job movers (see also De la Roca 2014). Izquierdo and Puente (2015) suggest that there has been a structural change after the 2012 labor reform, which changed the regulation of wage bargaining (García-Pérez and Jansen 2015), as they find a $0.13 \mathrm{pp}$ increase in the real wage elasticity for 2012Q3-2013Q4. Nonetheless, these elasticities are small in comparison with the estimates above unity in Pissarides (2009) for the US and several European countries. Moreover, the elasticity is countercyclical, i.e. the opposite of what would be needed to stabilize employment.
} 


\subsection{Self-reported reservation wages in the crisis}

We use data from the Spanish Survey of Family Finances (Encuesta Financiera de las Familias, EFF). This survey asks unemployed respondents the following question: "At what gross monthly wage would you be willing to work?". We keep only people who report a positive nominal reservation wage up to 4000 euros per month in any year. ${ }^{26}$ To avoid having in the sample people who exert little or no job search effort, we exclude respondents who report being unemployed for more than 5 years.

We pool together four waves, corresponding to years 2002, 2005, 2008, and 2011. The sample size is small, 2816 observations, of which 1538 are for men. The data constitute an incomplete panel, with the panel dimension being rather small, since around $80 \%$ of individuals are only observed once. For this reason, we estimate by pooling the data. The descriptive statistics of the variables are presented in Table 11. The average monthly reservation wage is around 1200 euros (at 2011 prices), the average duration is high-2 years, and one-third of individuals receive unemployment insurance benefits, while $10 \%$ get unemployment assistance benefits. By household, average gross real income is around 40,500 euros per year and average real net wealth is around 390,000 euros.

Our empirical specification is as follows:

$$
\log \left(\omega_{i t}\right)=\alpha_{t}+\beta \log \left(D u r_{i t}\right)+\gamma U I_{i t}+\delta U A_{i t}+X_{i t}^{\prime} \mu+u_{i t}
$$

where $i$ denotes an individual, $t$ is time, $\alpha_{t}$ is a year fixed effect, Dur is unemployment duration measured in years, $U I$ is an indicator for the receipt of unemployment insurance benefits, $U A$ is an indicator for the receipt of unemployment assistance benefits, and $X$ is a vector that contains the following variables: age, age squared, marital status (single, married, unmarried partner, separated, divorced), education (secondary first stage or less, secondary second stage, college), household-head status, household size (number of members), annual household gross real income (in the preceding year), real non-financial wealth, real financial wealth, and real debt. All monetary variables are deflated by the consumer price index, with 2011 as the base year. The EFF provides five imputations for missing values in most variables. We estimate the wage equation with each of the five data sets and then compute simple averages of the coefficients and corrected standard errors (Banco de España 2015). Standard errors are clustered at the household level.

In view of the small sample size, we report estimates for both the total sample, including a dummy variable for females, and for males alone. The first column of Table 7 shows that women have significantly lower reservation wages, but we should recall that, on average, women also earn lower wages even after controlling for observable characteristics.

Reservation wages are higher for male workers who are older, more educated, and married or cohabiting. They are also larger the higher are the household's size and income. Real assets are not significant, which may be the net outcome of a positive

\footnotetext{
26 There are only 11 observations above this threshold; keeping them slightly raises the estimated elasticity to unemployment duration.
} 
Table 7 Reservation wages

\begin{tabular}{|c|c|c|}
\hline & All & Males \\
\hline Log duration & $\begin{array}{c}-0.016^{* * *} \\
(0.006)\end{array}$ & $\begin{array}{c}-0.020^{* *} \\
(0.008)\end{array}$ \\
\hline Contributory benefits & $\begin{array}{l}0.055^{* * *} \\
(0.015)\end{array}$ & $\begin{array}{c}0.021 \\
(0.020)\end{array}$ \\
\hline Assistance benefits & $\begin{array}{c}0.013 \\
(0.021)\end{array}$ & $\begin{array}{r}-0.022 \\
(0.029)\end{array}$ \\
\hline Age & $\begin{array}{l}0.004^{* * *} \\
(0.001)\end{array}$ & $\begin{array}{l}0.005^{* * *} \\
(0.001)\end{array}$ \\
\hline Female & $\begin{array}{c}-0.159^{* * *} \\
(0.013)\end{array}$ & \\
\hline Married & $\begin{array}{l}0.059^{* * *} \\
(0.018)\end{array}$ & $\begin{array}{l}0.070^{* * *} \\
(0.026)\end{array}$ \\
\hline Unmarried partner & $\begin{array}{l}0.057^{* *} \\
(0.028)\end{array}$ & $\begin{array}{l}0.107^{* * *} \\
(0.041)\end{array}$ \\
\hline Separated & $\begin{array}{c}0.033 \\
(0.040)\end{array}$ & $\begin{array}{c}0.011 \\
(0.055)\end{array}$ \\
\hline Divorced & $\begin{array}{l}0.076^{* *} \\
(0.048)\end{array}$ & $\begin{array}{c}0.054 \\
(0.062)\end{array}$ \\
\hline Household head & $\begin{array}{c}-0.014^{* *} \\
(0.006)\end{array}$ & $\begin{array}{r}-0.011 \\
(0.007)\end{array}$ \\
\hline Secondary education, 2 nd stage & $\begin{array}{l}0.031^{* *} \\
(0.014)\end{array}$ & $\begin{array}{l}0.048^{* *} \\
(0.020)\end{array}$ \\
\hline College & $\begin{array}{l}0.070^{* * *} \\
(0.014)\end{array}$ & $\begin{array}{l}0.056^{* * *} \\
(0.018)\end{array}$ \\
\hline Household size & $\begin{array}{l}0.224^{* * *} \\
(0.022)\end{array}$ & $\begin{array}{l}0.194^{* * *} \\
(0.032)\end{array}$ \\
\hline Total income & $\begin{array}{l}0.014^{* *} \\
(0.007)\end{array}$ & $\begin{array}{l}0.024^{* *} \\
(0.012)\end{array}$ \\
\hline Real assets & $\begin{array}{c}0.001 \\
(0.002)\end{array}$ & $\begin{array}{c}0.002 \\
(0.002)\end{array}$ \\
\hline Financial assets & $\begin{array}{l}0.013^{* * *} \\
(0.002)\end{array}$ & $\begin{array}{l}0.011^{* * *} \\
(0.003)\end{array}$ \\
\hline Debt & $\begin{array}{l}0.005^{* * *} \\
(0.001)\end{array}$ & $\begin{array}{l}0.005^{* *} \\
(0.002)\end{array}$ \\
\hline Observations & 2816 & 1358 \\
\hline $\mathrm{R}^{2}$ & 0.251 & 0.262 \\
\hline
\end{tabular}

Dependent variable: $\log$ monthly reservation wage

The specification includes also year dummy variables. Standard errors are clustered at the household level. $* p<0.10, * * p<0.05, * * * p<0.01$ 
(a)

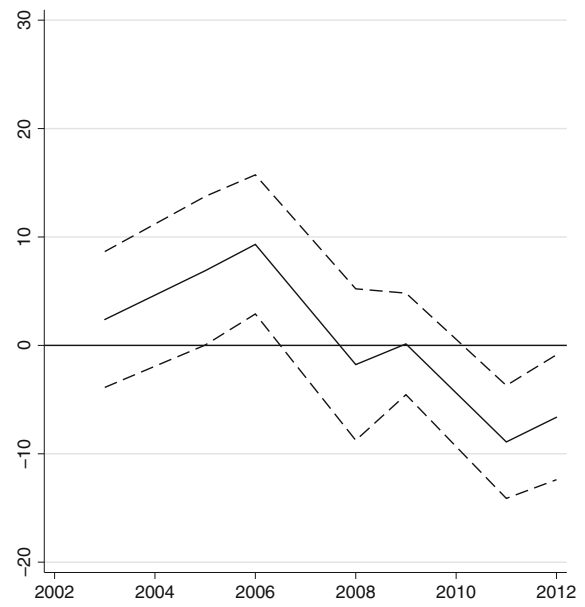

(b)

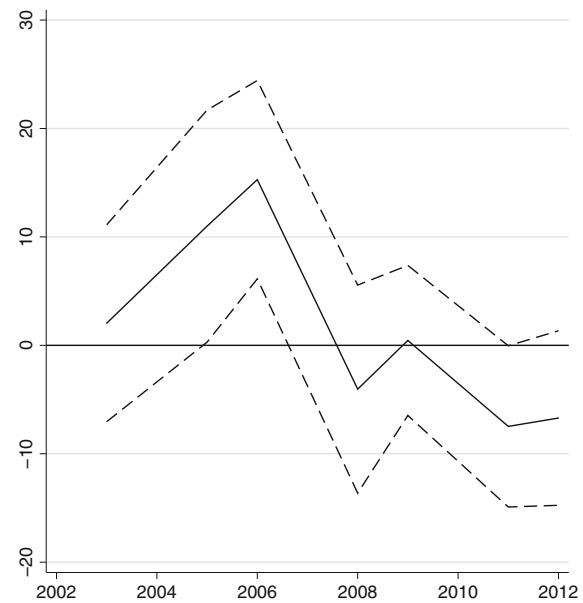

Fig. 11 Annual profile of reservation wages, deviations from $2002(\%)$ a Full sample, b Males. Source: own computations. Dashed lines represent $95 \%$ confidence intervals

wealth effect and a negative lock-in effect stemming from homeownership. Financial assets, which are more liquid, do exert a positive impact on reservation wages, and debt attracts a positive sign, so that it is not net wealth that matters. Receipt of contributory benefits is significant for the full sample but not for males, and assistance benefits are not significant for any sample.

An important coefficient is the elasticity of the reservation wage to unemployment duration, which is equal to $-1.6 \%$ overall and to $-2.0 \%$ for males. These are very small elasticities, which suggest that reservation wages do not respond very strongly to unemployment duration. On the other hand, the profile of the coefficient on the yearly dummy variables, depicted in Fig. 11, shows that self-reported reservation wages do indeed trace the business cycle. Taking 2002 as the reference, there are significant increases for all workers in the boom years of 2005 and 2006, and large reductions in 2011 and 2012. The pattern is even stronger for males, although it is estimated with less precision due to the smaller number of observations. While, as already mentioned, male wages in our MCVL sample fell by $15.3 \%$ from 2009 to 2014, average selfreported reservation wages already show a reduction by 2008 and the cumulated fall by 2012 is equal to $16.8 \%$. Therefore, both figures are quite consistent with each other, suggesting that reservation wages capture an important element in the wages received by workers who reentered employment. In any case, such a large reduction in reservation wages forcefully suggests the lack of room for much further adjustment in reservation wages.

In comparison with the existing literature on self-reported reservation wages, we control better for the financial situation of households. Our findings are at variance with the results in Koenig et al. (2016), who use data on self-reported reservation wages in the United Kingdom and Germany-from 1991 to 2009 and from 1984 to 2010, respectively - and find low and borderline significant elasticities to the aggregate unemployment rate. Outside the self-reported reservation wage literature, however, the 
strong and volatile cyclical behavior, that we associate with our coefficients on the time fixed effects is also found by Chodorow-Reich and Karabarbounis (2016). These authors compute, for the US from 1961 to 2012, the flow value of the opportunity cost of employment, dividing it into a benefit component and the forgone value of nonworking time. While the first component is small and countercyclical, the second one-which is closer to our measure, since we are controlling for the receipt of unemployment benefits-is procyclical and volatile over the business cycle.

The low response of reservation wages to the receipt of unemployment benefits has also been found by Krueger and Mueller (2016). These authors collected a Survey of Unemployed Workers in New Jersey, in 2009-2010, and they cannot find a significant relationship between reservation wages and benefits. As in our sample, however, these wages are positively correlated with financial variables like severance payments and savings. Lastly, our results partially differ from those in Addison et al. (2009), who use data from the European Community Household Panel over 1994-1999. Only in 7 out of 13 countries in their sample do self-reported reservation wages respond significantly to the receipt of unemployment benefits, but Spain is one of them, with a significant coefficient of 0.092. However, their equation is less informative than ours, since it only includes gender, schooling, age, and time fixed effects as controls. On the other hand, they do not find a significant elasticity of the reservation wage to unemployment duration in most countries, but in the Spanish case it is significant and low, around $1 \%$, which is smaller but close to our estimates.

\section{Conclusions}

We have analyzed the determinants of the buildup and persistence of exceptionally high levels of LTU in Spain during the Great Recession. Our empirical analysis indicates that mature age, low experience, and entitlement to UI benefits are the main risk factors. Low educational attainment and skill also raise the chances of entering LTU, especially if we mitigate the relevance of spells below 1 month. Moreover, two of our most striking findings are the relatively low risk of LTU for workers from the construction sector and the pervasive presence of negative duration dependence. The job-finding hazard of the average worker drops by 53\% during the first 12 months and it halves again during the next 12 months. These effects are much larger than most cross-sectional differences in job-finding rates across unemployed workers with the same duration. Lastly, job-finding rates become less responsive to improvements in aggregate labor market conditions as unemployment spells lengthen.

Our estimates imply that growth alone will not be sufficient to significantly lift the job-finding rates of the long-term unemployed. Moreover, the room for further wage adjustments seems very limited due to the large observed fall in average reentry wages that is matched by a strong decline in self-reported reservation wages. An overall implication of our analysis is therefore that the current levels of LTU entail a substantial risk of social and economic exclusion. Spain should step up its efforts to design effective active labor market policies that help to improve the employment prospects of the long-term unemployed.

Our study offers no clear prescriptions for the design of efficient active labor market policies for the long-term unemployed. Nonetheless, the recent meta-analysis of Card 
et al. $(2015 \mathrm{a}, \mathrm{b})$ indicates that these policies can make a significant contribution to the reduction of unemployment and especially of LTU. Investments in training and hiring incentives that are carefully targeted at the LTU deliver the best long-term results while public employment programs tend to have the worst performance, but impact estimates vary considerably across different studies. The appropriate design of the programs is therefore crucial and interventions ought to be tailored to the needs of each participant. If these conditions are satisfied, the programs for the long-term unemployed are often both effective and cost-efficient (Csillag and Fertig 2015).

After a long period of inaction, Spanish policymakers are slowly recognizing the need to develop effective tools to fight LTU. Following a recent recommendation of the European Council, Spanish authorities have approved a 3-year program (Programa de Acción Conjunta para Desempleados de Larga Duración) to offer individualized support to one million long-term unemployed people. This support involves the assignment to a personal tutor and the preparation of an individual integration agreement. However, this is nothing but the first step. Spain has a poor track record in the field of active labor market policies and its public employment services are outdated and play at best a marginal role as intermediaries in the labor market (Jansen 2016a, b). These problems need to be addressed before we may expect positive results from the recently announced plan.

Moreover, with a view to the future, it is essential to intensify the early activation of the unemployed. In particular, this is crucial for unemployed workers who receive benefits, so that they do not reach spell durations at which, due to duration dependence, low exit rates condemn them to enter and remain in long-term unemployment. As noted in Jansen (2016b), in 2015 registered unemployed workers had to wait on average more than 9 months before receiving their first service from the public employment services and around one-third of them were already in LTU at the time when they received it. Early activation should act as a preventive tool that impedes the quick buildup of a large stock of long-term unemployed.

Open Access This article is distributed under the terms of the Creative Commons Attribution 4.0 International License (http://creativecommons.org/licenses/by/4.0/), which permits unrestricted use, distribution, and reproduction in any medium, provided you give appropriate credit to the original author(s) and the source, provide a link to the Creative Commons license, and indicate if changes were made.

\section{Appendix}

\section{Additional empirical results}

This Appendix provides additional empirical results on the exit rate from unemployment and reservation wages.

\section{Hazard rates and survival probabilities}

See Tables 8, 9 and 10. 
Table 8 Estimates of the hazard of leaving unemployment

\begin{tabular}{|c|c|c|c|c|c|c|c|c|}
\hline & \multicolumn{4}{|c|}{ Expansion } & \multicolumn{4}{|c|}{ Recession } \\
\hline & \multicolumn{2}{|c|}{$\begin{array}{l}\text { Exit to temporary } \\
\text { contract }\end{array}$} & \multicolumn{2}{|c|}{$\begin{array}{l}\text { Exit to permanent } \\
\text { contract }\end{array}$} & \multicolumn{2}{|c|}{$\begin{array}{l}\text { Exit to temporary } \\
\text { contract }\end{array}$} & \multicolumn{2}{|c|}{$\begin{array}{l}\text { Exit to permanen } \\
\text { contract }\end{array}$} \\
\hline & Coeff. & $\mathrm{Z}$ & Coeff. & $\mathrm{z}$ & Coeff. & $\mathrm{z}$ & Coeff. & $\mathrm{z}$ \\
\hline Age $35-44$ years old & -0.035 & -0.89 & 0.180 & 2.05 & -0.106 & -4.69 & 0.232 & 4.36 \\
\hline Age $45-54$ years old & -0.586 & -4.16 & 0.442 & 2.04 & -0.295 & -5.00 & 0.438 & 3.79 \\
\hline $\begin{array}{l}\text { Age } 35-44 \text { y.o. } \times \log \\
\text { Dur }\end{array}$ & -0.064 & -2.51 & -0.038 & -0.65 & -0.018 & -1.55 & -0.135 & -4.34 \\
\hline $\begin{array}{l}\text { Age } 45-54 \text { y.o. } \times \log \\
\text { Dur }\end{array}$ & -0.006 & -0.07 & -0.127 & -0.93 & -0.067 & -2.06 & -0.210 & -3.07 \\
\hline $\begin{array}{l}\text { Secondary } \\
\text { education, } 1 \text { st. }\end{array}$ & 0.107 & 2.66 & -0.033 & -0.32 & 0.160 & 4.86 & -0.185 & -2.41 \\
\hline $\begin{array}{l}\text { Secondary } \\
\text { education, } 2 \text { st. }\end{array}$ & -0.079 & -1.75 & -0.093 & -0.82 & 0.103 & 2.72 & -0.111 & -1.31 \\
\hline College education & -0.348 & -6.64 & -0.117 & -0.92 & -0.024 & -0.53 & 0.101 & 1.05 \\
\hline $\begin{array}{l}\text { Secondary ed } 1 \\
\text { st. } \times \log \text { Dur }\end{array}$ & 0.008 & 0.33 & 0.147 & 1.96 & 0.003 & 0.19 & 0.166 & 3.43 \\
\hline $\begin{array}{l}\text { Secondary ed. } 2 \\
\text { st. } \times \log \text { Dur }\end{array}$ & 0.004 & 0.14 & 0.172 & 2.17 & -0.035 & -1.83 & 0.180 & 3.45 \\
\hline $\begin{array}{l}\text { College } \\
\text { education } \times \log \\
\text { Dur }\end{array}$ & 0.018 & 0.60 & 0.191 & 2.25 & -0.027 & -1.16 & 0.193 & 3.33 \\
\hline High skill & 0.093 & 2.64 & 0.224 & 2.67 & 0.273 & 7.38 & 0.015 & 0.18 \\
\hline Medium skill & 0.187 & 6.29 & -0.079 & -0.98 & 0.347 & 10.11 & -0.155 & -1.92 \\
\hline High skill $\times \log$ Dur & -0.088 & -4.09 & 0.020 & 0.37 & -0.093 & -5.01 & 0.173 & 3.48 \\
\hline $\begin{array}{l}\text { Medium skill } \times \log \\
\text { Dur }\end{array}$ & -0.071 & -3.82 & 0.130 & 2.40 & -0.071 & -4.15 & 0.171 & 3.49 \\
\hline Dismissal & 0.259 & 12.67 & -0.004 & -0.08 & 0.601 & 26.33 & -0.469 & -12.19 \\
\hline Experience & 0.471 & 12.89 & 1.730 & 18.47 & 1.031 & 31.63 & 1.596 & 22.48 \\
\hline$\Delta$ Employment & 2.405 & 3.37 & -5.286 & -3.06 & 4.142 & 14.25 & 2.904 & 3.78 \\
\hline $\begin{array}{l}\Delta \text { Employment } \times \log \\
\text { Dur }\end{array}$ & -0.663 & -1.50 & 1.122 & 0.96 & -0.711 & -4.49 & -0.002 & 0.00 \\
\hline Unemployment rate & 0.010 & 1.19 & -0.220 & -14.25 & -0.017 & -5.63 & -0.066 & -10.51 \\
\hline $\begin{array}{l}\text { Unempl. rate } \times \log \\
\text { Dur }\end{array}$ & -0.021 & -3.63 & 0.053 & 4.13 & 0.006 & 4.94 & 0.019 & 6.57 \\
\hline Labor reform 2010 & & & & & -0.072 & -3.25 & -0.073 & -1.27 \\
\hline Labor reform 2012 & & & & & 0.009 & 0.51 & 0.158 & 3.47 \\
\hline $\log$ Dur & -0.378 & -4.43 & -0.991 & -5.21 & -0.693 & -13.77 & -0.850 & -7.06 \\
\hline$(\log \text { Dur })^{2}$ & 0.255 & 6.22 & -0.052 & -0.47 & 0.337 & 11.37 & -0.032 & -0.39 \\
\hline$(\log \text { Dur })^{3}$ & -0.066 & -7.28 & 0.000 & -0.01 & -0.104 & -16.79 & -0.029 & -1.72 \\
\hline $\begin{array}{l}\text { Unemployment } \\
\text { insurance }\end{array}$ & -0.436 & -33.82 & -0.381 & -11.92 & -0.380 & -37.52 & -0.157 & -7.04 \\
\hline $\begin{array}{l}\text { Unemployment } \\
\text { insurance }^{2}\end{array}$ & 0.042 & 22.32 & 0.031 & 6.84 & 0.035 & 24.83 & 0.014 & 4.55 \\
\hline
\end{tabular}


Table 8 continued

\begin{tabular}{|c|c|c|c|c|c|c|c|c|}
\hline & \multicolumn{4}{|l|}{ Expansion } & \multicolumn{4}{|l|}{ Recession } \\
\hline & \multicolumn{2}{|c|}{$\begin{array}{l}\text { Exit to temporary } \\
\text { contract }\end{array}$} & \multicolumn{2}{|c|}{$\begin{array}{l}\text { Exit to permanent } \\
\text { contract }\end{array}$} & \multicolumn{2}{|c|}{$\begin{array}{l}\text { Exit to temporary } \\
\text { contract }\end{array}$} & \multicolumn{2}{|c|}{$\begin{array}{l}\text { Exit to permanent } \\
\text { contract }\end{array}$} \\
\hline & Coeff. & $\mathrm{z}$ & Coeff. & $\mathrm{z}$ & Coeff. & $\mathrm{z}$ & Coeff. & $\mathrm{z}$ \\
\hline $\begin{array}{l}\text { Unemployment } \\
\text { insurance }^{3}\end{array}$ & -0.001 & -17.91 & -0.001 & -4.76 & -0.001 & -20.30 & 0.000 & -3.80 \\
\hline $\begin{array}{l}\text { U. insurance } \times \log \\
\text { Dur }\end{array}$ & -0.026 & -3.55 & -0.039 & -2.51 & -0.024 & -4.95 & -0.035 & -3.28 \\
\hline $\begin{array}{l}\text { U. insurance } \times(\log \\
\text { Dur })^{2}\end{array}$ & 0.006 & 1.63 & 0.021 & 2.80 & 0.009 & 3.95 & 0.009 & 1.85 \\
\hline U. assistance & -1.083 & -32.14 & -1.086 & -11.38 & -1.107 & -46.11 & -1.287 & -18.78 \\
\hline $\begin{array}{l}\text { U. assistance } \times \log \\
\text { Dur }\end{array}$ & 0.036 & 1.44 & 0.111 & 1.63 & 0.030 & 1.96 & 0.187 & 4.29 \\
\hline No. of spells & 37,399 & & & & 62,045 & & & \\
\hline No. of observations & $1,346,016$ & & & & $1,641,889$ & & & \\
\hline Log likelihood & $-352,712.09$ & & & & $-446,462.87$ & & & \\
\hline
\end{tabular}

The sample is made up of males aged 25-54 years old. The expansion corresponds to the period 2001-2007 and the recession to 2008-2014

Table 9 Unobserved heterogeneity estimates, 2001-2014

\begin{tabular}{lllll}
\hline & Expansion & & \multicolumn{2}{l}{ Recession } \\
\hline Types & Coeff. & $\mathrm{z}$ & \multicolumn{1}{l}{ Coeff. } & $\mathrm{z}$ \\
$\eta_{1}^{u}$ & -2.19 & -17.98 & -1.83 & -23.20 \\
$\eta_{2}^{u}$ & -0.96 & -7.93 & -3.17 & -40.97 \\
$\eta_{1}^{e}$ & -2.68 & -14.37 & -3.59 & -23.58 \\
$\eta_{2}^{e}$ & -1.73 & -9.24 & -2.59 & -16.94 \\
Probabilities & & & & \\
$\operatorname{Pr}\left(\eta_{\text {high }}^{u}, \eta_{\text {low }}^{e}\right)$ & 0.32 & 17.93 & 0.23 & 10.18 \\
$\operatorname{Pr}\left(\eta_{\text {high }}^{u}, \eta_{\text {high }}^{e}\right)$ & 0.15 & - & 0.11 & 3.68 \\
$\operatorname{Pr}\left(\eta_{\text {low }}^{u}, \eta_{\text {low }}^{e}\right)$ & 0.50 & 30.48 & 0.58 & - \\
$\operatorname{Pr}\left(\eta_{\text {low }}^{u}, \eta_{\text {high }}^{e}\right)$ & 0.03 & 6.63 & 0.08 & 11.99 \\
\hline
\end{tabular}

The sample is made up of males aged $25-54$ years old

Table 10 Survival rates in unemployment at 12 and 24 months with censoring of short jobs (\%)

\begin{tabular}{lllll}
\hline & Expansion & \multicolumn{3}{l}{ Recession } \\
\cline { 2 - 5 } & 12 months & 24 months & 12 months & 24 months \\
\hline $\begin{array}{llll}\text { Overall } \\
\text { Age }\end{array}$ & 26.7 & 48.0 & 42.9 & 65.7 \\
25-34 years old & 26.2 & 47.2 & 40.7 & 63.6 \\
35-44 years old & 28.4 & 52.0 & 45.3 & 68.0 \\
$45-54$ years old & 40.1 & 63.7 & 52.5 & 75.5 \\
\hline
\end{tabular}


Table 10 continued

\begin{tabular}{|c|c|c|c|c|}
\hline & \multicolumn{2}{|l|}{ Expansion } & \multicolumn{2}{|l|}{ Recession } \\
\hline & 12 months & 24 months & 12 months & 24 months \\
\hline \multicolumn{5}{|l|}{ Education } \\
\hline Primary or less & 27.5 & 47.8 & 47.6 & 67.8 \\
\hline Secondary, 1st st. & 24.1 & 44.2 & 42.7 & 63.6 \\
\hline Secondary, 2nd stage & 27.5 & 46.6 & 42.8 & 64.0 \\
\hline College & 30.8 & 48.2 & 40.1 & 61.4 \\
\hline \multicolumn{5}{|l|}{ Skill } \\
\hline High & 27.9 & 50.3 & 43.6 & 66.8 \\
\hline Medium & 24.6 & 46.1 & 40.9 & 64.2 \\
\hline Low & 28.4 & 48.0 & 46.8 & 67.1 \\
\hline \multicolumn{5}{|l|}{ Experience } \\
\hline $\mathrm{P} 75$ & 19.0 & 39.2 & 31.4 & 56.0 \\
\hline P50 & 22.6 & 43.5 & 37.8 & 61.6 \\
\hline $\mathrm{P} 25$ & 32.8 & 54.1 & 50.7 & 71.6 \\
\hline $\mathrm{P} 10$ & 43.1 & 63.4 & 63.4 & 80.0 \\
\hline \multicolumn{5}{|l|}{ Industry } \\
\hline Manufacturing & 22.1 & 42.2 & 38.4 & 61.0 \\
\hline Construction & 23.3 & 46.2 & 40.1 & 62.4 \\
\hline Non-market services & 31.2 & 52.0 & 47.4 & 71.1 \\
\hline Trade & 26.1 & 44.9 & 42.2 & 63.8 \\
\hline Hospitality & 24.5 & 42.6 & 38.3 & 61.9 \\
\hline Other services & 30.8 & 53.2 & 46.4 & 70.1 \\
\hline \multicolumn{5}{|l|}{ Unemployment insurance } \\
\hline No benefits & 16.0 & 35.5 & 28.3 & 53.4 \\
\hline 6 months & 25.1 & 35.5 & 36.4 & 53.4 \\
\hline 12 months & 46.2 & 35.5 & 54.8 & 53.4 \\
\hline 18 months & 55.2 & 45.8 & 63.7 & 61.8 \\
\hline 24 months & 63.4 & 65.9 & 71.4 & 75.5 \\
\hline \multicolumn{5}{|c|}{ Unemployment assistance } \\
\hline No & 16.0 & 35.5 & 28.3 & 53.4 \\
\hline Yes & 43.8 & 62.1 & 59.5 & 76.6 \\
\hline \multicolumn{5}{|l|}{ Business cycle } \\
\hline High growth & 24.6 & 44.6 & 39.2 & 64.1 \\
\hline Low growth & 28.9 & 51.6 & 46.1 & 67.0 \\
\hline
\end{tabular}

The sample is made up of males aged 25-54 years old. The expansion corresponds to the period 2001-2007 and the recession to 2008-2014. The probability for the 24th month is computed after resetting it to 100 at 12 months 


\section{Descriptive statistics of the reservation wage sample}

See Table 11.

Table 11 Descriptive statistics for the reservation wage sample

\begin{tabular}{lrr}
\hline & \multicolumn{1}{c}{ Mean } & SD \\
\hline Reservation wage (monthly) & $1,177.3$ & 511.5 \\
Unemployment duration & 2.0 & 1.4 \\
Contributory benefits & 33.1 & 51.6 \\
Assistance benefits & 9.8 & 32.6 \\
Age & 36.6 & 13.8 \\
Female & 45.4 & 54.5 \\
Single & 50.4 & 54.8 \\
Married & 36.6 & 52.8 \\
Unmarried partner & 5.1 & 24.2 \\
Separated & 3.5 & 20.1 \\
Divorced & 3.3 & 19.4 \\
Household head & 35.5 & 52.4 \\
Secondary education, 1st stage or less & 45.8 & 54.6 \\
Secondary education, 2nd stage & 35.7 & 52.5 \\
College & 18.5 & 42.5 \\
Household size & 3.5 & 1.5 \\
Total income & $40,532.6$ & $59,082.0$ \\
Real assets & $350,236.4$ & $700,874.5$ \\
Financial assets & $7,356.3$ & $360,404.6$ \\
\hline Debt & $38,007.4$ & 22.5 \\
\hline
\end{tabular}

2816 observations. All variables are percentage shares except monetary variables, which are in 2011 euros, age and unemployment duration which are in years, and household size which is the number of members

\section{References}

Abraham K, Sandusky K, Haltiwanger J, Spletzer JR (2016) The consequences of long-term unemployment: evidence from matched employer-employee data, US Census Bureau Center for Economic Studies Paper CES-16-40

Abbring JH, van den Berg GJ (2004) Analysing the effect of dynamically assigned treatments using duration models, binary treatment models, and panel data models. Empir Econ 29(1):5-40

Addison JT, Centeno M, Portugal P (2009) Do reservation wages really decline? Some international evidence on the determinants of reservation wages. J Labor Res 30(1):1-8

Arranz JM, García-Serrano C (2014) The interplay of the unemployment compensation system, fixed-term contracts and rehirings: the case of Spain. Int J Manpow 35(8):1236-1259

Arranz JM, García-Serrano C, Toharia L (2010) The influence of temporary employment on unemployment exits in a competing risk framework. J Labor Res 31(1):67-90

Banco de España (2015) The Spanish Survey of Household Finances (EFF) 2011 User Guide. Unit of Microeconomic Information and Analysis. http://www.bde.es/f/webbde/SES/estadis/eff/ficheros/en/ UserGuide_2011.pdf 
Bentolila S, Dolado JJ, Jimeno JF (2012) Reforming an insider-outsider labor market: the Spanish experience. IZA J Eur Labor Stud 1(4):1-29

Bentolila S, García-Pérez JI, Jansen M (2017) Are the Spanish long-term unemployed unemployable? Fedea, Working Paper 2017/02

Bentolila S, Jansen M (2016) Long-term unemployment after the Great Recession: causes and remedies. CEPR Press, London

Bentolila S, Jansen M, Jiménez G (2016) When credit dries up: job losses in the Great Recession. CEMFI, mimeo, Madrid

Bonhomme S, Hospido L (2017) The cycle of earnings inequality: evidence from Spanish social security data. Econ J doi:10.1111/ecoj.12368

Bover O, Arellano M, Bentolila S (2002) Unemployment duration, benefit duration, and the business cycle. Econ J 112(479):223-265

Bover O, Gómez R (2004) Another look at unemployment duration: exit to a permanent vs. a temporary job. Investig Econ 28(2):285-314

Card D, Kluve J, Weber A (2015a) Active labour market policies and long-term unemployment. In: Bentolila S, Jansen M (eds) Long-term unemployment after the Great Recession: causes and remedies. CEPR Press, London

Card D, Kluve J, Weber A (2015b) What works? A meta analysis of recent active labor market program evaluations, IZA Discussion Paper 9236

Carrasco R, García-Pérez JI (2015) Employment dynamics of immigrants versus natives: evidence from the boom-bust period in Spain, 2000-2011. Econ Inq 53(2):1038-1060

Chodorow-Reich G, Karabarbounis L (2016) The cyclicality of the opportunity cost of employment. J Political Econ 124(6):1563-1618

Csillag M, Fertig M (2015) Cost-benefit analysis of remedial interventions for the long-term unemployed. Directorate-General for Employment, European Commission, Brussels

De la Roca J (2014) Wage cyclicality: evidence from Spain using social security data. SERIEs J Span Econ Assoc 5(2):173-195

De la Roca J, Puga D (2016) Learning by working in big cities. Rev Econ Stud 84(1):106-142

Elsby MWL, Hobijn B, Şahin A (2015) On the importance of the participation margin for labor market fluctuations. J Monet Econ 72:64-82

Farré L, Fasani F, Mueller H (2015) Feeling useless: the effect of unemployment on mental health in the Great Recession, Barcelona GSE Working Paper 838

Font P, Izquierdo M, Puente S (2015) Real wage responsiveness to unemployment in Spain: asymmetries along the business cycle. IZA J Eur Labor Stud 4:13

García Pérez JI (1997) Las tasas de salida del empleo y el desempleo en España (1978-1993). Investig Econ 21(1):29-53

García Pérez JI (2008) La Muestra Continua de Vidas Laborales (MCVL): una guía de uso para el análisis de transiciones. Rev Econ Apl 16(E-1):5-28

García-Pérez JI, Jansen M (2015) Assessing the impact of Spain's latest labour market reform. Span Econ Financ Outlook 4(May):5-15

García-Perez JI, Muñoz-Bullón F (2011) Transitions into permanent employment in Spain: an empirical analysis for young workers. Br J Ind Relat 49(1):103-143

Gaure S, Roed K, Zhang T (2007) Time and causality: a Monte Carlo assessment of the timing-of-events approach. J Econ 141(2):1159-1195

Heckman J, Singer B (1984) A method for minimizing the impact of distributional assumptions in econometric models for duration data. Econometrica 52(2):271-320

Izquierdo M, Puente S (2015) Wage response to changes in the cyclical situation: an estimate based on MCVL social security administrative labour records. Banco de España, Economic Bulletin (June), pp 21-25

Jansen M (2016a) Peer review on approaches to integrate long-term unemployed persons. Peer country comments paper-Spain. European Commission, Directorate-General for Employment, Social Affairs and Inclusion, Brussels

Jansen M (2016b) The provision of integrated support to the long-term unemployed, New Skills at Work Second Report. Fedea and JPMorgan Chase Foundation, Madrid

Jansen M, Jiménez-Martín S, Gorjón J (2016) The legacy of the crisis: the Spanish labour market in the aftermath of the Great Recession Fedea Working Paper 2016/10 
Jenkins S (1995) Easy estimation methods for discrete-time duration models. Oxf Bull Econ Stat 57(1):129_ 138

Jimeno JF, Santos T (2014) The crisis of the Spanish economy. SERIEs J Span Econ Assoc 5(2):125-141

Koenig F, Manning A, Petrongolo B (2016) Reservation wages and the wage flexibility puzzle, IZA Discussion Paper 9717

Krueger AB, Cramer J, Cho D (2014) Are the long-term unemployed on the margins of the labor market? Brookings Papers on Economic Activity (Spring), pp 229-280

Krueger AB, Mueller AI (2016) A contribution to the empirics of reservation wages. Am Econ J Econ Policy 8(1):142-179

Kroft K, Lange F, Notowidigdo MJ, Katz L (2016) Long-term unemployment and the Great Recession: the role of composition, duration dependence, and nonparticipation. J Labor Econ 34(S1):S7-S54

Lacuesta A, Puente S, Villanueva E (2012) Sectoral change and implications for occupational mismatch in Spain. Banco de España, Economic Bulletin (July), pp 97-105

Lancaster K (1990) The economic analysis of transition data. Cambridge University Press, Cambridge

Layard R, Nickell S, Jackman R (1991) Unemployment. Macroeconomic performance and the labour market. Oxford University Press, Oxford

Leibovich M, Barrett G (2009) The buzzwords of 2009. New York Times. Week in Review, December 19, http://www.nytimes.com/2009/12/20/weekinreview/20buzz.html?_r=1\&ref=weekinreview

Machin S, Manning A (1999) The causes and consequences of long-term unemployment in Europe. In: Ashenfelter O, Card D (eds) Handbook of labor economics, vol 3. Elsevier, Amsterdam, pp 3085-3139

Meyer B (1990) Unemployment insurance and unemployment spells. Econometrica 58(4):757-82

Moffit (2014) Unemployment benefits and unemployment. IZA World of Labor 13. doi:10.15185/izawol. 13

Nagore A, van Soest A (2016a) New job matches and their stability before and during the crisis. CentER Discussion Paper 2016-033

Nagore A, van Soest A (2016b) Unemployment exits before and during the crisis, LISER Working Paper 2016-14

Pissarides CA (2009) The Unemployment volatility puzzle: is wage stickiness the answer? Econometrica 77(5):1339-1369

Rebollo-Sanz Y, García-Pérez JI (2015) Are unemployment benefits harmful to the stability of working careers? The case of Spain. SERIEs J Span Econ Assoc 6(1):1-41

Rebollo-Sanz Y, Rodríguez-Planas N (2016) When the going gets tough... Financial incentives, duration of unemployment and job-match quality. IZA Discussion Papers 10044

Saint-Paul G (1996) Are the unemployed unemployable? Eur Econ Rev 40(7):1501-1519

van den Berg GJ (2001) Duration models: specification, identification, and multiple durations. In: Heckman JJ, Leamer E (eds) Handbook of Econometrics, vol 5. Elsevier, Amsterdam, pp 3381-3460

Winter-Ebmer R (2016) Long-term effects of unemployment: what can we learn from plant-closure studies? In: Bentolila S, Jansen M (eds) Long-term unemployment after the Great Recession: causes and remedies. CEPR Press, London 